\title{
Event stratigraphy of the upper Cretaceous to lower Eocene hemipelagic sequences of the Prebetic Zone (SE Spain): Record of the onset of tectonic convergence in a passive continental margin
}

\author{
Javier Martín-Chivelet ${ }^{\mathrm{a}, *}$, Beatriz Chacón ${ }^{\mathrm{a}, \mathrm{b}}$ \\ a Departament॰ de Estratigrafia, Institut de Geologia Económica, CSIC-UCM, Facultad de Ciencias Geológicas, \\ E-2804 Madrid, Spain \\ b Fachbereich Geowissenschaften, Universität Bremen, D-28334 Bremen, Germany
}

\begin{abstract}
In the Eastern Prebetic Zone of SE Spain, upper Cretaceous to lower Eocene hemipelagic sequences deposited in the ancient southern passive continental margin of lberia are well exposed. The long-term stratigraphy of these sequences is punctuated by six regional tectonic events, which induced rapid changes in palaeogeography and regional tectonics. Each event configured a new genetic scenario for sedimentation, which lasted until the next tectonic reorganization and, in turn, controlled the deposition of an event bounded stratigraphic unit (EBSU). The ages of these events, determined chronobiostratigraphically, are: intra-Coniacian, late Santonian, "mid" Maastrichtian, latest Maastrichtian earliest Danian, late Thanetian and intra-Ypresian. All the events, but the first, are interpreted here as the result of contractional tectonic pulses, related to changes in intraplate stresses during the onset of African European convergence. Through correlations with both adjacent shallow marine carbonates (Prebetic platform) and basin pelagites (Subbetic), along with other basins of Iberia and North Africa, the long-term evolution of the continental margin is integrated within the geodynamic framework of the western Tethys.
\end{abstract}

Kegwerds: Event stratigraphy; Hemipelagites; Late Cretaceous; Palaeocene; Betics; Spain

\section{Introduction}

Event stratigraphy is an excellent tool for subdividing stratigraphic records and establishing high-reselution correlations between coeval successions of different depesitional settings in a sedimentary basin. It is particu-

\footnotetext{
* Corresponding author. Tel.: +34913944817 ; fax: +34913944808 . E-mail addresses: j.m.chivelet@geo.ucm.es (J. Martin-Chivelet), bchacon@geo.ucm.es (B. Chacón).
}

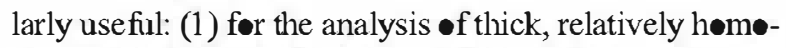
geneous, deep marine successions, where sea-level changes are not clearly recorded and biestratigraphic studies are incompatible with high reselution stratigraphy; and (2) for detailed correlations between such homogeneous successions and their correlative shallow marine sequences, in the absence of a well preserved platform-tobasin transition.

These tw circumstances $\bullet$ ccur in most pelagic/ hemipelagic carbonate series that breadly developed in 
the western Tethys during latest Mesøzic and earliest Cenoz•ic times. These series form wide and relatively homogeneous pelagic/hemipelagic units - such as the "scaglia" facies of Italy and the "chalk" sequences of Western Europe - which, despite their utility for hydrecarbon exploration, are difficult to subdivide and analyse. In addition, their correlation with nearby shallow carbonate platforms is usually problematic and limits further understanding of the evelution of sedimentary basins.

The upper Cretaceous and Palaeocene hemipelagic carbønates analyzed in this paper are not exempt from these problems. These carbønates were depesited in the ancient southern continental margin of Iberia - the scalled Betic Margin - and, for years, have been difficult to subdivide and precisely correlate with coeval shallow marine successions, mainly because of the lack $\bullet$ precise elements for time-correlations (e.g., Vera et al., 1982).

In this paper, we report the long-term event stratigra-

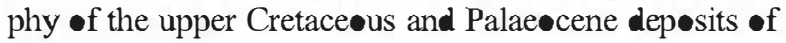
the proximal hemipelagic/pelagic settings of the Betic Margin and discuss the relationship between the events identified and the development of the basin, its tectonic history and gløbal events.

\section{Geological framework and study area}

The Prebetic is a bread Alpine tectonic unit that correspønds to the outer portion of the foreland fold-andtbrust belt of the Betic Cordillera, in SE Spain. It consists

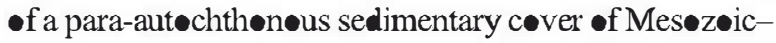
Cen॰z^ic age, which became detached from the Variscan basement along Upper Triassic evaporites during the main -regenic stage, in the Early and Middle Miocene. The sedimentary cover was originally deposited in the southern continental margin of Iberia (Fig. 1), a basin derived from the break-up and divergence of Africa and Eurøpe in the Mesezøic, which during the late Cretaceous-early Cenøz॰ic underwent transition from a passive to a convergent margin (e.g., Martín-Chivelet et al., 2002).

The Prebetic unit includes thick carbenate successions (up to $1000 \mathrm{~m}$ ) of Late Cretace us and Early Palae gene age that were depesited in environments ranging from coastal to bathyal. On the basis of these series and from a palaenge graphical perspective, we differentiate between a north-western area, or Prebetic Platform, defined by the dominance of shallow marine carbønates, and a søuth-eastern regiøn, or Hemipelagic Prebetic, characterized by deeper facies (Fig. 1). Unfortunately, the platform-to-basin transition is peorly preserved, since the platform margin was strongly deformed during final compression episedes.
This repørt føcuses $\bullet$ the Hemipelagic Prebetic area, spanning most of the Alicante prevince and part of the Murcia province in SE Spain (Fig. 1). This zøne, with excellent exp॰sures $\bullet$ f upper Cretace us and Palae•gene hemipelagites, •ccupies a unique palaeøge graphical pesition, between the shalløw carbønate settings of the "Prebetic platform" (e.g., Fourcade, 1970; Azema et al., 1979; Martín-Chivelet, 1992) and the deepest pelagic envirønments •f the Subbetic (e.g., García Hemández et al., 1980; Vera, 1986; 1988). The latter constitutes an alløchthøn us tectønic unit, •verthrusting the søuthern-

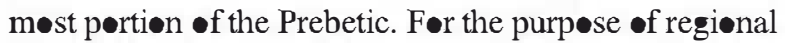
comparisøns, we alsø examined the Subbetic Zøne near Caravaca le la Cruz, a world-wide reference area for the study of gløbal biøevents (i.e., Cretace $\bullet$-Palaeøene - K/P - and Palaeocene-Eocene - P/E bøundaries: Canud• et al., 1991; M•lina et al., 1994; Canude et al., 1995; M॰lina et al., 1998; Kaih॰ and Lam॰lda, 1999; Arz et al., 2000; M•lina et al., 2005; Chacón and Martín-Chivelet, 2005a; amøng •thers).

\section{Methods and data}

The stratigraphic analysis of møn॰t॰n॰us sedimentary successions, in which relative sea level changes are barely recorded, requires that we de-emphasis "pure" sequence stratigraphic metheds and search for altemative criteria to chronestratigraphically subdivide and genetically interpret sedimentary infill at time scales of $10^{5}-10^{6}$ years. Among these criteria, the recognition and characterization of stratigraphic events (and the stratigraphic reck units they bound) in such sedimentary record appears as a useful to॰l.

Using this approach to analyse and correlate the late Cretaceus and Palaeøcene hemipelagic carbønate successions of the Prebetic, we characterized a series -f stratigraphic events that can be traced, at least on a regional scale. These events, and the resultant event bounded stratigraphic units (EBSUs) comprise a new regienal stratigraphic framework and a sound basis for interregional correlations.

The concept of "event" in the stratigraphic literature is rather different depending on the authors and their scientific disciplines (e.g., Einsele et al., 1991; Walliser, 1996; Einsele, 1998). In the present work, the terms "event" and "event horizen" are used in a wide

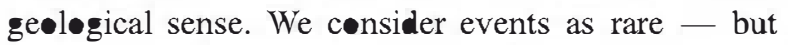
n॰t necessarily exceptional - and rapid - but n॰t strictly instantane us - precesses that •ccur in (or affect) a region. These incidents can be of different $\bullet$ rigin and duration and can cause abrupt changes in sedimen-

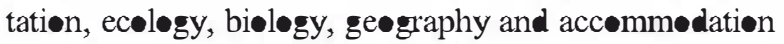


Location of the main pre-orogenic palaeogeographic units

in the Betics-Rif System:

1.- External Betics (S. Iberian Margin)

2.- Internal Betics (Alboran Block)

3.- Internal Rif (Alboran Block)

4.- External Rif (Tellian Margin)

5.- Tell (Tellian Margin)

6.- Kabilias (Alborán Block)

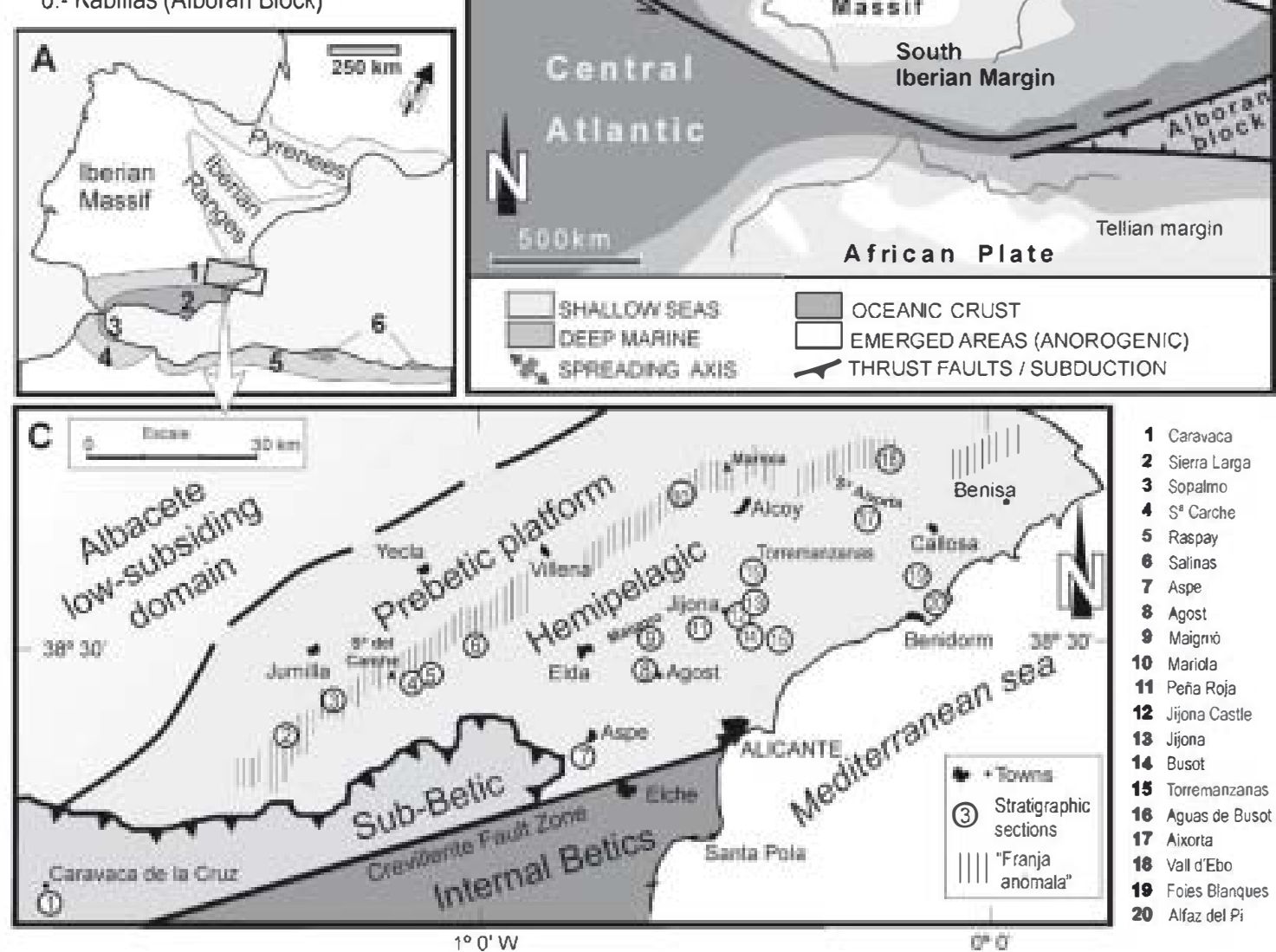

Fig. 1. Geological and palaeogeographical location of the study area. A) Present location in the westem Mediterranean of the main CretaceousPalaeocene palaeogeographic domains and basins, including the ancient southern continental margin of Iberia. B) Late Cretaceous (late Santonian) palaeogeographic reconstuction of the same area according to Ziegler (1988). C) Location of the study area and main stratigraphic sections in SE Spain cited in this paper. This map shows the main tectonic units and palaeogeographical features mentioned in the text.

patterns. The stratigraphical records of such events are the event horizons, which can be depesitional, nondepesitional or eresienal (e.g., Einsele, 1998). As the respense to an event may be different depending on the environment, water-depth, geographic location, etc., event horizons always change laterally. The same event can be recorded at different locations in a basin as a sedimentary bed, as an unconformity, as a hiatal surface, or as a rapid change in the sedimentary facies or fossil assemblages.

An important aspect to consider is that each event not -nly represents a short time interval during which cer- tain envirømental conditiøns are provisionally altered, but als• induces substantial permanent palae ge graphical and basin changes that last until the next event takes place. Thus, each event prepares the scenery for the next EBSU to be generated, and each EBSU constitutes a genetic unit that comprises deposits generated in different, yet cœetaneœus, sedimentary settings, genetically related by a series of tectonosedimentary and envirømental conditions, which prevail until abruptly modified by the following event. These genetic conditions invelve, amøng ๑ther aspects, subsidence patterns, palae ge•graphy, water-depth, and envirøments. 


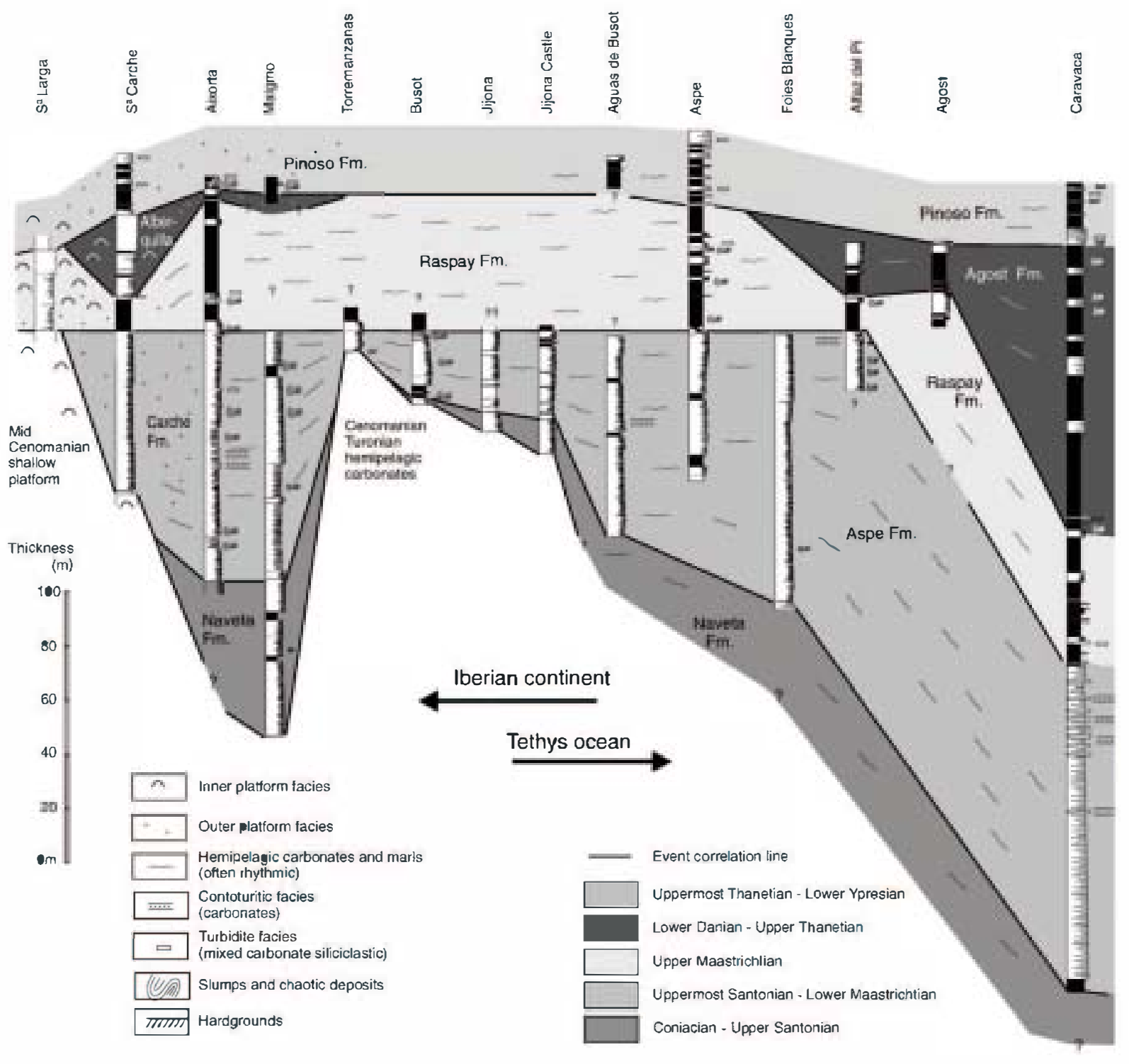

Fig. 2. Correlation panel for the Coniacian to Ypresian interval in the "Hemipelagic Prebetic". The section of Caravaca (Subbetic) has also been included. Note that the horizontal scale is arbitrary, and that logs are arranged according to their palaeogeographic proximity to land.

The results herein presented are based on the study of 20 stratigraphic sections and several løcal ๑utcrops that were investigated in detail for the Coniacian to Ypresian interval (Fig. 1). Facies analysis permitted the characterization of sedimentary environments and their changes throughout these sections, and biestratigraphic studies, mainly based on the distribution of planktonic foraminifera (detailed in Chacón et al., 2004), have allowed the precise age-dating of the successions. In these studies, six main event horizens were characterized, dated and correlated. The horizons subdivide the upper Coniacian to Ypresian series int five main rock packages or EBSUs.
The distributions of event horizons, lithostratigraphic units, biøzenes and EBSUs are shøwn in Figs. 2, 3 and 4.

The duration of these EBSUs ranges from less than 3 million years to more than 10 . The events eccurred much more rapidly and always in time lapses notably shørter than their chrøn॰biestratigraphy is capable of reselving.

\section{Event stratigraphy and basin development}

In this section, the løng-term develøpment of the hemipelagic/pelagic domains of the Prebetic is presented 


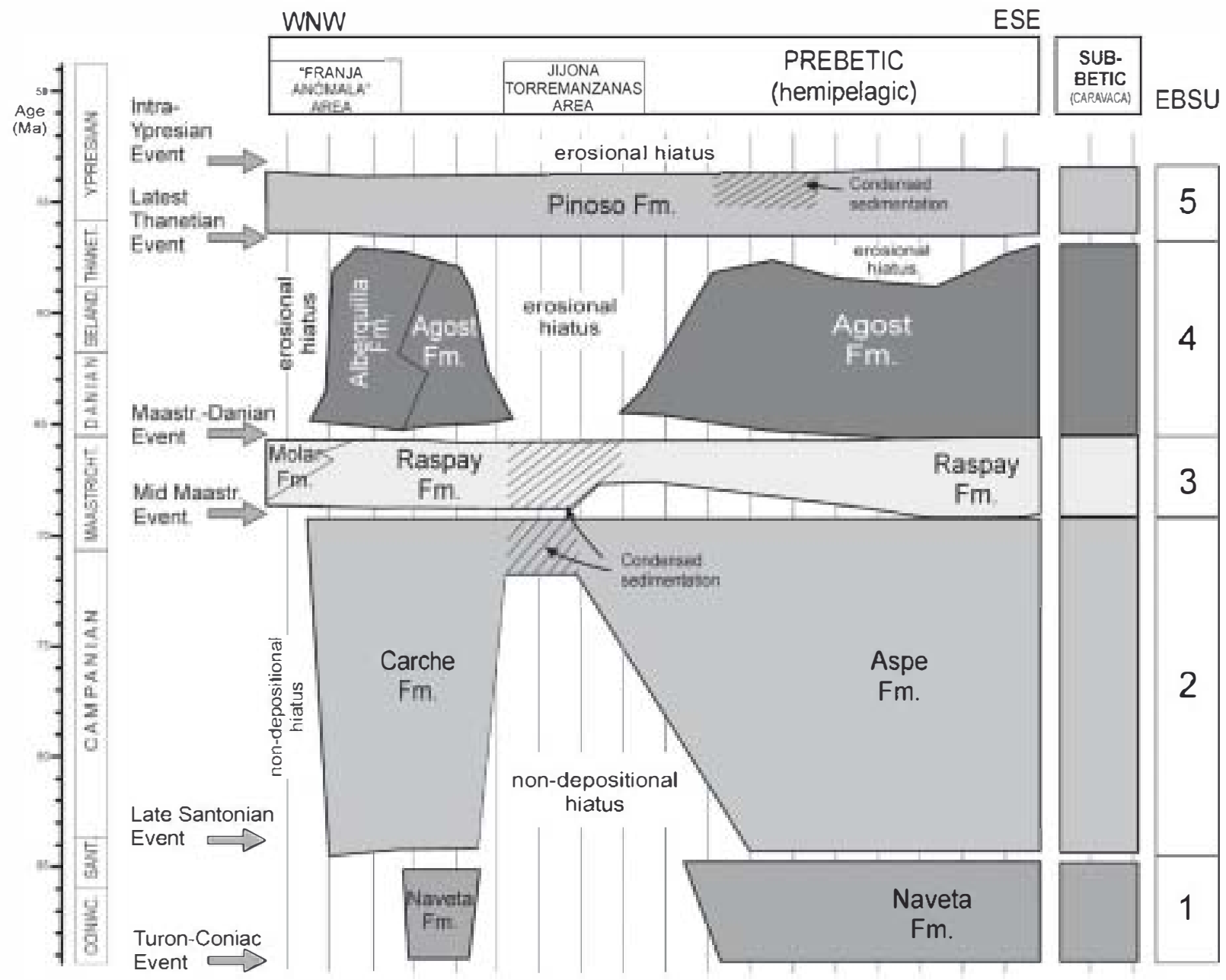

Fig. 3. Chronostratigraphic summary chart for the Coniacian-Ypresian interval showing spatial and temporal distributions of lithostratigraphic units, hiatuses and event bounded units (EBSUs). Time scale after Gradstein et al. (2004).

for the interval late Coniacian to Ypresian. This section is organized according to the six main event horizons identified in the study area and to the sedimentation that took place between each tw $\bullet$ successive events, recorded in the five event bounded stratigraphic units. All events and units are described in chrøn॰løical $\bullet$ rder.

\subsection{Pre-Coniacian basin development}

In the Betic Margin, the late Albian-mid Cenomanian interval is characterized by a remarkable absence of tectonic activity, with thermal cœeling of the lithosphere and eustatic changes being the main factors controlling basin accommødation changes (Martín-Chivelet, 2003). Aløng with the mid Cretace us sea level highstand, this situation allowed the spread of shallow marine waters tens of kilømetres landwards, giving rise to the widest

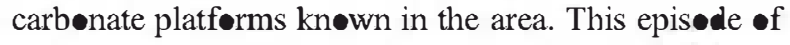

relative tectonic quiescence ended however in the mid Cenomanian, which saw the start of a tectonically unstable peried continuing until the early-middle Coniacian. Tectonic activity, repørted in different areas $\bullet$ the Prebetic (e.g., Hoedemaeker, 1973; De Ruig, 1992; Martín-Chivelet, 1992, 1995, 1996; Chacón, 2002; Chacón and Martín-Chivelet, 2003), provoked a complex scenery of topøgraphic highs and trøughs, in response to multi-phase reactivation or the generation of listric faults.

On the Prebetic Platform, listric fault movements caused the develøpment of an ENE-WSW complex trough with shallow marine carbonate sedimentation, bounded by twe elevated and emergent areas lacking sedimentation (Martín-Chivelet, 1995). One of these areas, towards the NW, roughly cøincides with the søcalled Albacete Domain, a stable, low subsident, semicratønic zøne attached to the continent. The other area, to 


\section{EBSU-5}

Morozovella subbotinae

Acaninina soldadoensis
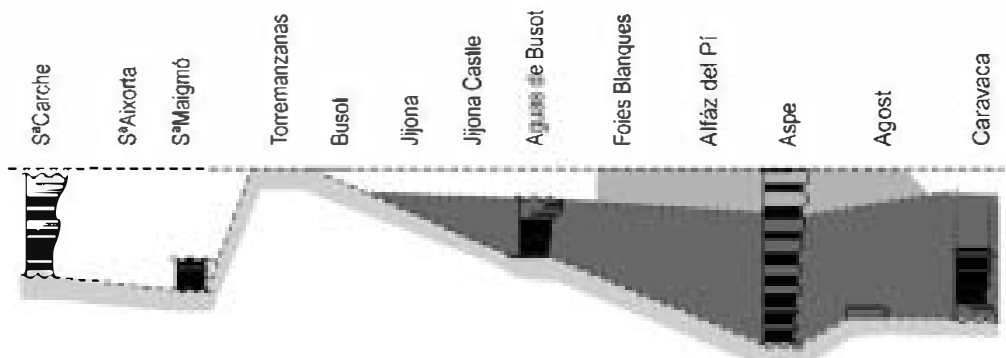

\section{EBSU-4}

Globanomalina pseudomenardi

Igorina pusilla

Morozovella angulata

Praemurica uncinata

Praemulica trinidadensis

Parasubbotina pseudobulloides

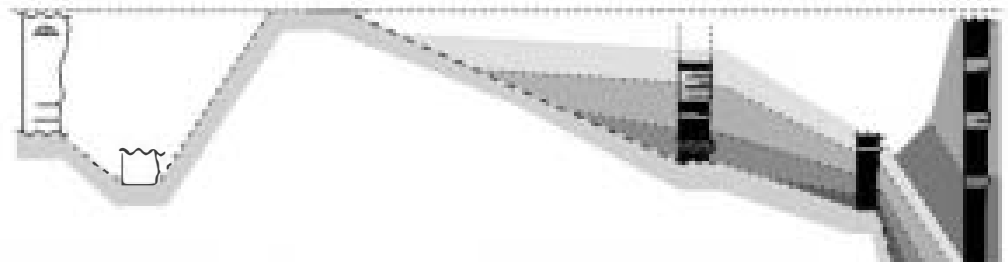

Iberian continent

Tethys ocean

\section{EBSU-3}

Abathomphalus mayaroensis

Gansserina

(upper part)

\section{EBSU-2}
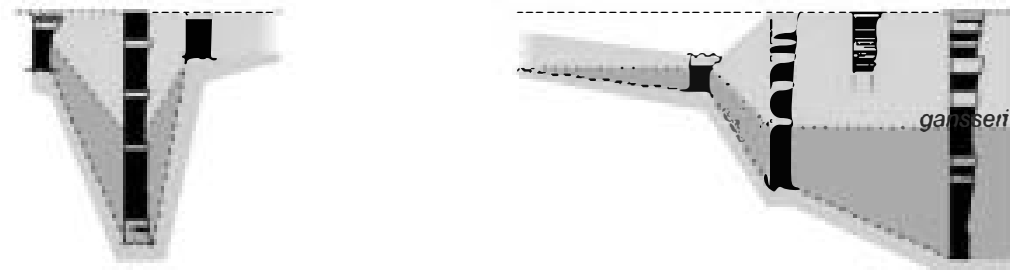

Gansserina ganssen (lower/middle part)

Globotruncana falsostuart

Globotruncanita calcarata

Globotruncana ventricosa

Globotruncanita elevata

Dicarinella asymetrica

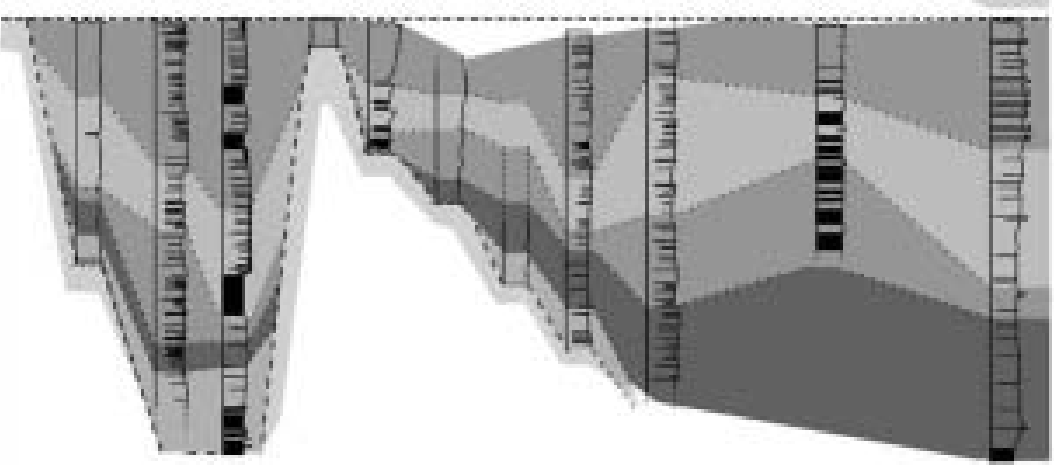

\section{EBSU-1}

Dicarinella asymetrica

Dicarinella concavata

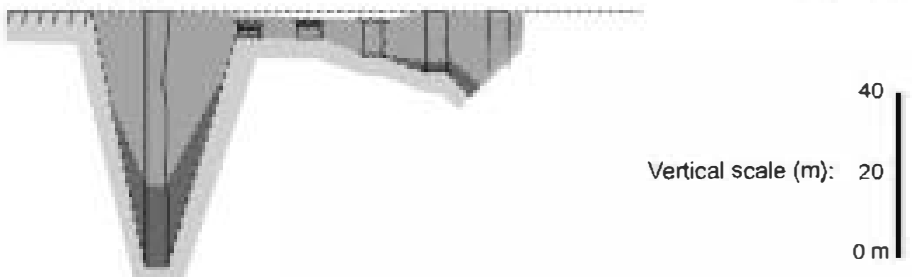

Fig. 4. Biocorrelation panel for each of the five event bounded units differentiated in this paper, showing the distribution of the main biozones of planktonic foraminifera. 

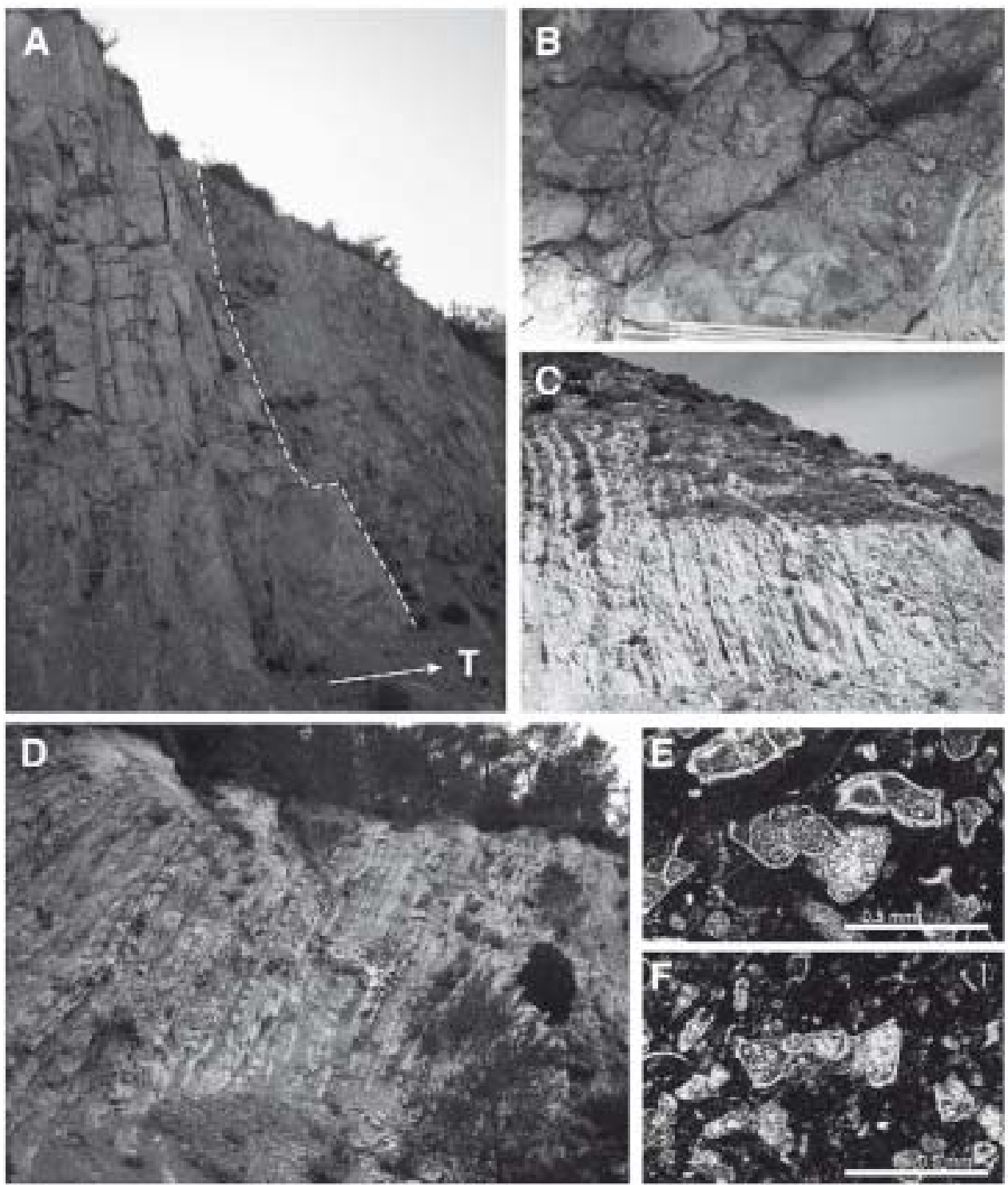

Fig. 5. Field aspects of the Turonian-Coniacian event and EBSU-1. A) Discontinuity (outlined) in the Busot section. White arrow marks the top of the section. B) Bioturbation and micritic lithoclasts included at the base of EBSU-1 after the Turonian-Coniacian event in the Maigmó section. C) Monotonous hemipelagic succession of limestones and marly limestones of EBSU-1 (Naveta Fm) in the Jijona section. D) Part view of EBSU-1 (Naveta Fm) in the Maigmó section. E-F) Diagnostic planktonic foraminifera species in EBSU-1: Dicarinell concuta (E) and icarinella asymerric (F)

the SE, corresponded to an emergent, narrow and intensely-eløngated bleck, which separates shallow waters from these of the hemipelagic area basinwards (Fig. 1). This area, designated Franja Anómala (“Anømaløus fringe") by Martínez del Olme et al. (1982), extended •ver several hundreds of kilømetres aløng the Prebetic for much of late Cretaceous, and constitutes the northwestem limit $\bullet$ the area considere in this paper.

Basinwards •f the Franja Anómala, late Cenømanian to

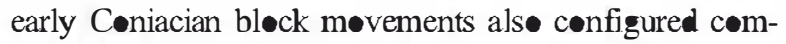

plex geometries of trøughs and permanently submerged highs, bounded by listric faults (De Ruig, 1992; Chacón, 2002). Troughs were partially filled by the discontinuous syntectonic deposition of hemipelagic carbønates and marls, with søme elisthøliths, whilst the highs became characterized by condensed hemipelagic sedimentation and/or hardground development (Chacón, 2002). Amøng these, the Torremanzanas High in the centre of the study area, formed a pøsitive topøgraphic feature during most $\bullet$ the Late Cretace us and probably the early Palaeøgene, 
separating shallower hemipelagic sediments to the $\mathrm{WNW}$ from deeper ones to the ESE (Figs. 2, 3 and 4). In this area, De Ruig (1992) described preserved listric faults that were active during the late Cenomanian-Turonian interval. These faults were sealed by early 'Senonian' depesits, suggesting that fault main activity ceased during latest Turønian or early Coniacian times, althøugh they later underwent several episødes $\bullet$ reactivation.

\subsection{Intra-Coniacian event}

The end $\bullet$ the main phases $\bullet$ tectønic møvements $\bullet$ the late Cenomanian-early Coniacian provoked a stratigraphic event, recorded regionally on a hiatal surface that represents a variable gap. Cenomanian to upper Turønian depesits were everlain by upper Coniacian, Santonian or even younger sediments. This heterøchrnicity is due to the inherited topography of the previous tectonic movements.

In the sections where minimum hiatuses were found (Maigmó and Jijøna Castle sections, see Fig. 1 for løcation), sedimentation after the event started in the late Coniacian (middle-upper part of the Dicarinella con-

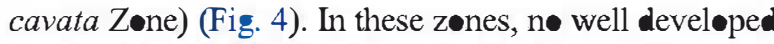
hardgrounds were found, but a net increase in bioturbation was $\bullet$ bserved towards the top of the underlying unit and small lithoclasts of these depesits appeared, incorporated in the basal level of the everlying unit (e.g., Maigmó), indicating sea fleor hardening and some erosion and reworking of the lithified sediment prior to the re-start of sedimentation (Fig. 5).

\subsection{EBSU-1 (upper Coniacian-upper Santonian p.p.)}

This renewed tectonic stability and topegraphy inherite from Cenømanian-Turønian tectønism (in which the Franja Anomala and the Torremanzanas High are the most prominent features), controlled hemipelagic sedimentation in the basin during the late Coniacian to the earlier part of the late Santonian interval. Asseciated with the previous topegraphy, pronounced changes in sediment thickness eccurred and the base of the successions shows significant heterochrønicity (Fig. 2). The unit is absent from the Franja Anómala (Carche, Salinas, Mariøla sections) and the Torremanzanas High (Torremanzanas section). In the Franja Anómala, there is some evidence of subaerial expesure for this period (Martín-Chivelet, 1992, 1995), whilst in the Torremanzanas High, prominent hardgrounds and condensed sections develøped.

Sedimentation in depressed areas is comprised of thin-bedded, nearly pure, fine grained hemipelagic biomicrites (Fig. 5). These limestones constitute fairly møn॰t॰nøus hemipelagic successions within the framework $\bullet \bullet$ nly $\bullet$ ne lith $\bullet$ stratigraphic unit, designated the Naveta Førmatiøn (Chacón and Martín-Chivelet, 2005b) (Fig. 3). The Naveta Fm is late Coniacian to late Santonian in age (it includes the middle-upper part of the D. concavata Zone and the Dicarinella asymetrica Zøne) and mainly consists of white wackestones with abundant calcispheres and planktonic foraminifers.

This sedimentation was endured until the late Santønian, when a new regiønal tectonic event took place in the basin. The tectenic episede, recorded in all the sedimentary successiens, marks the upper boundary of EBSU-1.

\subsection{Late Santonian event}

During the late Santenian interval, a regienal tectenic event affected the basin, substantially modifying the palae ge graphy and environmental conditions. Renewed fault movements led to regional subsidence variations and submergence of the top॰graphic high $\bullet$ the Franja Anómala.

This event was recognized in all the sections examined, although its stratigraphic record varies from one to another. In the depressed areas, where sedimentation was more continuous (Maigmó, Caravaca), the event was registered by a transitional zone within the hemipelagic sequences, in which a rapid increase in fine siliciclastics is the most obvious change. In other sections, such as Aixorta, the event is marked by a hiatal surface that is sometimes accompanied by a debris flow bed, reflecting some instability of the sea floor (Fig. 6). In the previously emerged Franja Anómala, the event represented a drastic palae ge graphic change: the area sunk rapidly leading to the development of open platform conditions. The resulting deposits, latest Santonian in age, overlay the palaeøalteration surface developed on mid Cenømanian shalløw marine carbønates. In contrast, the Torremanzanas High persisted as a submerged, elevated block, after the tectonic event.

The age of the event is late Santonian and occurred within the $D$. asymetrica Zøne (Aixørta, Maigmó). In places where there is discontinuity, the resumption of sedimentation after the event usually varies from latest Santønian (D. asymetrica Zøne, Carche section) to early Campanian (Globotruncanita elevata Zøne, Jijøna Castle section) (Fig. 4).

\subsection{EBSU-2 (uppermost Santonian-lower Maastrichtian)}

After the latest Santonian event, sedimentation continued in a hemipelagic setting comparable to that 

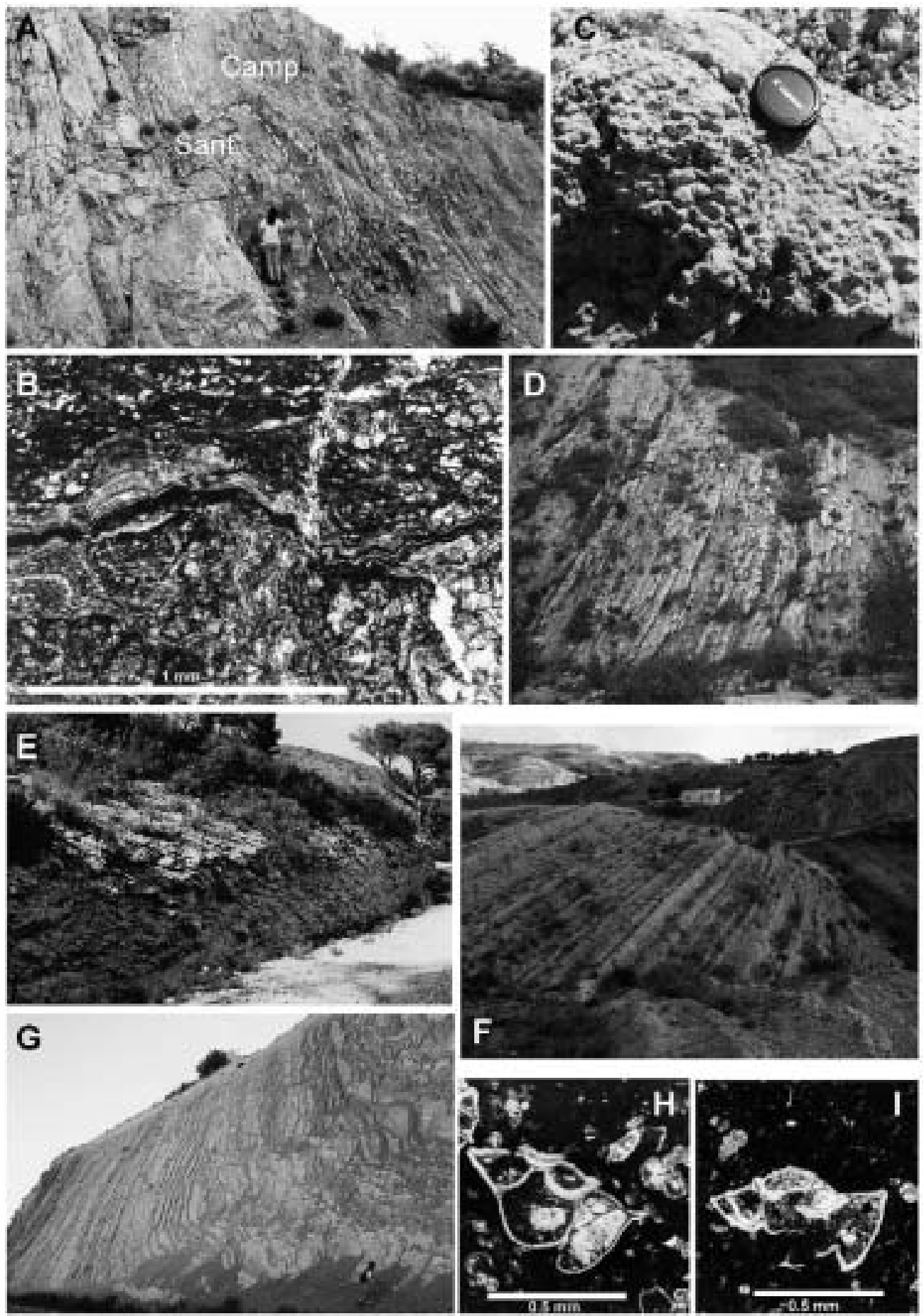

Fig. 6. A) Latest Santonian unconfonnity (outlined) in Busot, bounding Santonian deposits (top of EBSU-1) and upper Campanian sediments (EBSU- 2). The unconfornity is here marked by a hardground, and the associated hiatus includes the latest Santonian to early Campanian interval. B) Microphotograph of the hardground, showing pelagic microstromatolitic laminae. C) Debris flow deposit that marks the latest Santonian event in the Aixorta section. D, E, F and G) Different field aspect of EBSU-2 in (D) the Maigmó section (Carche Fm); (E) Carche section (Carche Fm); (F) Aspe section (Aspe Fm); and (G) Jijona-Torremanzanas area (Aspe Fm). H-I). Diagnostic planktonic foraminifera species in EBSU-2: Gløbtruncunita calcurata $(\mathrm{H})$ and Globetruncunita elevata $(\mathrm{I})$. 
EBSU-1, but with slightly deeper water-depths and the characteristic feature of including fine siliciclastic deposits. Sedimentation, however, took place in a new basin scenarie, in which the previously prominent topegraphic high of the Franja Anómala had disappeared.

These depesits are framed within EBSU-2, latest Santonian to early Maastrichtian in age. EBSU-2 is represented by tw• lith stratigraphic units (Fig. 3), røughly age equivalent, but showing substantial differences in facies, stratification and colour, the Carche Fm (Martín-Chivelet, 1994; Chacón and Martín-Chivelet, 2005b) and the Aspe Fm (Chacón and Martín-Chivelet, 2005b).

The Carche Formation crøps $\bullet$ ut in the north-western part of the study area (Carche, Salinas, Mariela, Vall

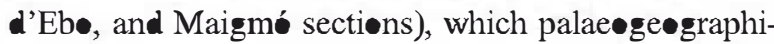
cally corresponds to shallower hemipelagic settings. It is 90 to $110 \mathrm{~m}$ thick and consists of light-coloured, often burrowed, limestenes and marly limestones, cœmmønly stratified in poorly-defined, 0.1-0.2 m thick, beds (Fig. 6D, E). These yield abundant planktonic and small benthic foraminifers, inøceramids, echinøids, and

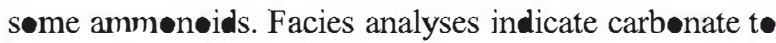
mixed hemipelagic settings, correspending to outer platform environments.

Laterally and basinwards, the Carche Formation grades int the Aspe Formation, depesited in hemi-

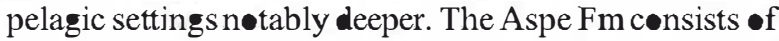
markedly rhythmic successions with altemations of white, pink and red limestones, marly limestones and marls (Fig. 6F, G). These successions are punctuated by $\mathbf{d m}$-scale beds of fine-grained calcarenites, showing abundant traction structures, which have been interprete as contøurite depesits (Martín-Chivelet et al., 2003). The presence of these tractive depesits is variable, being particularly abundant in the Caravaca area, suggesting a new configuration of $\bullet$ cean currents between Iberia and Africa. This passage constituted the main straits affecting the equatorial system of surface and subsurface currents (Philip and Flequet, 2000).

The Aspe Fm shows considerable lateral changes in thickness $(7-75 \mathrm{~m})$, especially in the Jijona-Torremanzanas area, where the unit partly covers the Torremanzanas High (Fig. 2). On this elevated blıck, highly condensed open-water successions were deposited. These include a succession of intensely mineralized hardgrøunds, rich in phøsphates and glaucønite, $\bullet$ ften showing fine pelagic stromatelitic laminae.

The age of the Carche Fm is latest Santonian to early Maastrichtian, as determined by planktonic foraminifera (Chacon et al., 2004). The unit comprises the following biøzones: $D$. asymetrica (॰nly its uppermest part), $G$. elevata, Globotruncana ventricosa, Globotruncanita calcarata, Globotruncana falsostuarti and Gansserina gansseri (only its lower-middle part). All these biøzones have been alse identified in the Aspe Fm, with the exception of the D. asymetrica Zøne. The Aspe Fm is considered earliest Campanian-early Maastrichtian in age.

\section{6. "Mid" Maastrichtian event}

A "mid" Maastrichtian tectonic event marked the end -f EBSU-2 depesition. This event abruptly changed the geometry and sedimentary conditions of the basin, and configured the new palaenge graphy that was to control the development $\bullet$ EBSU-3. The main changes $\bullet$ ccurring in the study area were: 1) tectonic movements giving rise to small, low-angle, inverse faults (Aspe sectiøn); 2) increased instability producing synsedimentary slumps, - listh liths and debris-flews; and 3) substantially enhanced siliciclastic influx, with marly sedimentation becoming dominant after the event.

The tectonic event is recorded in a regional unconformity. In the north-westernmest area, in the Carche section, this surface is marked by an iron-rich surface with a related minor hiatus. More to the south (Aspe section) (Fig. 7B), the event is recorded in a complex interval, revealing intense synsedimentary tectonism: the devel-pment of løw-angle, inverse faults, synsedimentary slumps and elisthelitbs (Chacón and Martín-Chivelet, 2001a). In the Subbetic of Caravaca, a debris-flow bed asseciated with the discontinuity is recøgnized (Fig. 7C). In $\bullet$ ther areas, a minør paraconformity $\bullet$ r even conformity, correlative to the described unconformity, may be -bserved (Alfaz del Pi, Maigmó, Aix orta). In all these outcrops, the event was marked by a rapid rise in the argillace us content of the facies.

The "mid" Maastrichtian event lasted a short time. The depesits immediately below the event horizøn have been date as early Maastrichtian (middle part of the $G$ gansseri Zøne) and th॰se resting •ver it are earliest late Maastrichtian (uppermøst part of the G. gansseri Zøne, characterized by the presence of Contusotruncana contusa and/or Racemiguembelina fructicosa) (Chacón and Martín-Chivelet, 2001b, 2003, 2005a).

\subsection{EBSU-3 (upper Maastrichtian)}

After the tectonic event, sedimentation resumed within a new mixed carbonate-siliciclastic, hemipelagic setting, characterized by an intense influx of fine terrigenous material and by much deeper environments than EBSU-2. T• the areas $\bullet$ the Franja Anómala that remained emerged (e.g., Sierra Larga), this event meant the resumption of 

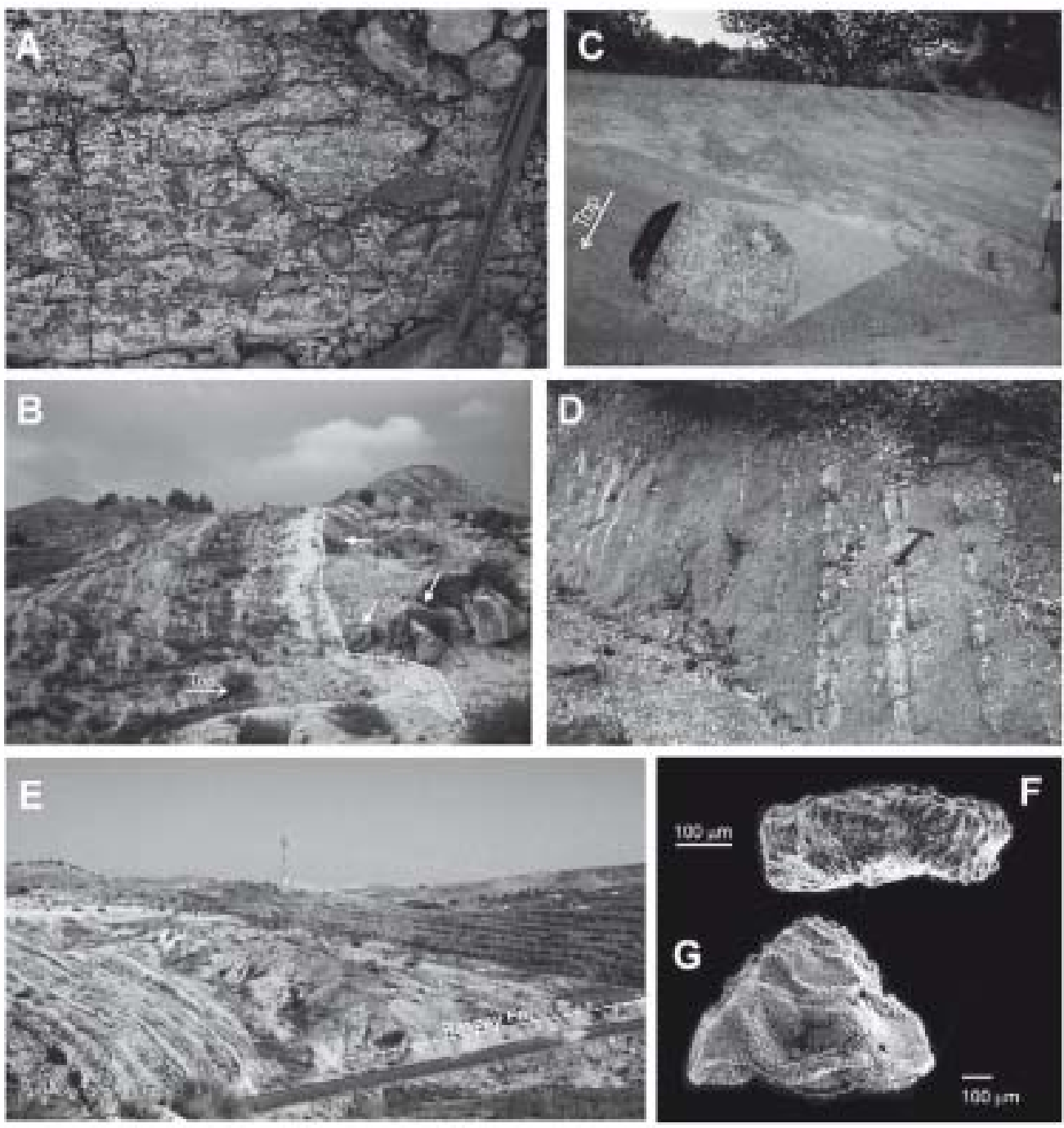

Fig. 7. A, B and C) Field aspects of the "mid" Maastrichtian event. Debris flow beds mark the event in both, Aixorta (A) and Caravaca (C). B) An unconfornity (outlined) separates the marly limestones of EBSU-2 from the marls of EBSU-3 in Aspe. The unconfornity surface is covered by shumps, and olistholiths (white arrows). D-E) Field aspects of the marls predominant in EBSU-3 (Raspay Fm), in Maigmó (D) and Aspe (E). F-G) SEM images of diagnostic planktonic foraminifera species from EBSU-3: Abth mphalus myarensis (F) and Contus•truncun contus (G).

sedimentation after more than 25 million years of subaerial exposure. These new conditions controlled the sedimentation of EBSU-3, which lasted until the end of the Maastrichtian.

EBSU-3 essentially consists of marls and marly limestønes, greenish t greyish cøloured, with søme fine limestone intercalations (Fig. 7D, E). These are framed within the Raspay Formation (Martín-Chivelet, 1994; Chacon and Martín-Chivelet, 2005b), which is 7 to $50 \mathrm{~m}$ thick and developed over all the study area, including the Torremanzanas High (Fig. 3). The unit contains rich asseciations of planktonic and benthic foraminifers,

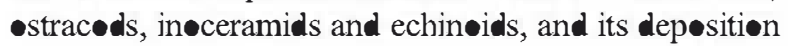
took place in a mixed hemipelagic setting, receiving a high fine terrigenous input and sporadic coarse grained turbidite currents, which yielded reworked fragments $\bullet$ shallow water biota, mainly orbit linids. The rich benthic foraminiferal assemblage (including Bolivinoides draco draco; Cibicidoides velascoensis; Coryphostoma incrassata; Globorotalites conicus; Nuttallinella florealis; and Reussella szajnochae; among others) has enabled an approximation to the water-depth of $200 \mathrm{~m}$ or deeper, according to the palae bathymetry estimations of Van Morkhoven et al. (1986). Sea floor instability is variable spatially, but in some areas (Aspe, Alfaz del Pí) stratification is strengly disturbed by synsedimentary slumps.

The age of EBSU-3 is late to latest Maastrichtian, as it includes the upper part of the G. gansseri Zøne and 
the Abathomphalus mayaroensis Zøne (Fig. 4). Unlike the previous units, the onset of EBSU-3 sedimentation was practically contemporaneous all $\bullet$ ver the study area, with the exception $\bullet$ the Torremanzanas High, where ne sedimentation took place until the latest Maastrichtian. At this pøint the unit records its minimum thickness (less than $7 \mathrm{~m}$ ) and consists of a condensed sequence of reddish, nødular, marly limestenes to marls.

\subsection{Maastrichtian-Danian boundary event}

At the end of the Maastrichtian, a new event took place in the basin, indicating the end of EBSU-3 depesition. This new event caused abrupt changes in subsidence, water-depth, biotic assemblages, environments and sedimentary conditions, and prepared the basin for the depesition of EBSU-4 (Danian to late Thanetian interval). The causes of this event were complex owing to a superpesitioning of regiønal tectonics, that induced bløck movements and differential subsidence, along with the envirømental and biøløgical effects of the CretaceousPalae cene (KP) bøundary gløbal event.

The record of the event in the basin was found to be different depending on the area. Cløse to land (Carche, Aix orta), the rate of hemipelagic sedimentation rapidly decreased until ceasing at the end of the Maastrichtian. As a result, an intensely burrowed, bored and mineralized hardground formed (Fig. 8A, B), which eventually became colønized by epibenthøic gastropeds and brachiøp॰ds. On this surface, $\bullet$ pen marine, phøsphate strømat•lites develøped (Chacón and Martín Chivelet, 1999; Chacón, 2002). Sedimentation in these areas did n七t restart until the early (but n๑t earliest) Danian (Carche, Aix rta) or much later, as far as the Thanetian.

Basinwards, the record of the event does not reflect the development of a sedimentary discontinuity. This is the case of the sections of Agest and Caravaca, where the Maastrichtian-Danian transition has a very complete record. Owing to their completeness and the excellent exposure, these sections have become world references for the Cretaceous/Palae gene boundary (Canude et al., 1991, M•lina et al., 1996, 1998, 2005, among ethers).

Regienally, the Maastrichtian-Danian event marked the intense reorganization of sedimentary environments. After the event, the north-westernmest areas recorded a decrease in water-depth, and carbenate outer to inner shallow platforms developed over the hemipelagic depøsits $\bullet$ the Raspay Fm basinwards. On the contrary, in the southeastern sectors the water-depth rapidly rose and mixed hemipelagic sedimentation continued, although turbidite currents became more abundant.
The regional event took place between the end of the Maastrichtian and the beginning of the Danian. The Maastrichtian-Danian horizen separates the A. mayaroensis Zøne bearing depesits from sediments that include the $G$. cretacea $+P$. longiapertura Zøne

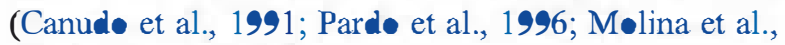
1996; Chacón, 2002).

\subsection{EBSU-4 (lower Danian-upper Thanetian)}

EBSU-4 was depesited under the new envirenmental and palaege graphical conditions generated during the Maastrichtian-Danian event, which prevailed until the late Thanetian. We should mention that the sedimentary record of this unit is quite incomplete over most of the study area, and that the interpretations herein presented are limited by the scarcity of $\bullet$ utcrøps of this age.

The previous event probably determined the generation of a submerged top॰graphy, with prøfound bathymetric differences. Water-depths ranged from very shallow, with the develøpment of reef carbønates in the Carche section, to bathyal in the søuthernmest areas (Caravaca, Agest). Topøgraphic highs possibly developed in some areas, as suggested by the hardgrounds and strongly condensed sections that formed in the Aixorta area.

EBSU 4 is represented by twe lithestratigraphic units: the Alberquilla Fm and Agest Fm (Chacón, 2002; Chacón and Martín-Chivelet, 2005b). Beth units are age equivalent, althøugh n• lateral intermediate facies were -bserved between them (Figs. 2 and 3).

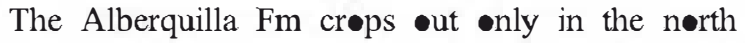
westernmest zones of the analyzed area, that would palae@ge日graphically correspend to the shallowest areas, nearer the emerged lands. It is $30 \mathrm{~m}$ thick and is formed in its lower part by white to beige, thinly stratified, fine bieclastic, wackestones, rich in rounded planktønic foraminifera, søme micrøbenthic foraminif-

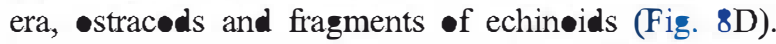
Upwards, these limestones grade int white, coarser wackestones to grainstones, with abundant large benthic foraminifera, remains of red algae, echinids, bryøzøans and bivalves, and massive reefal framestones, with cølonial cørals and red algae. The vertical succession $\bullet$ facies reveals a rapid transition from proximal outer platform environments to an inner platform, reefal/ parareefal setting.

The age estimation of the Alberquilla Fm is mainly based on large benthic foraminifera, which are abundant in its middle and upper parts (Fig. 8F-G). Three Shallow Benthic Zones (SBZ) - 2, 3 and 4 (as defined by Serra-Kiel et al., 1998) — were recøgnized here. 

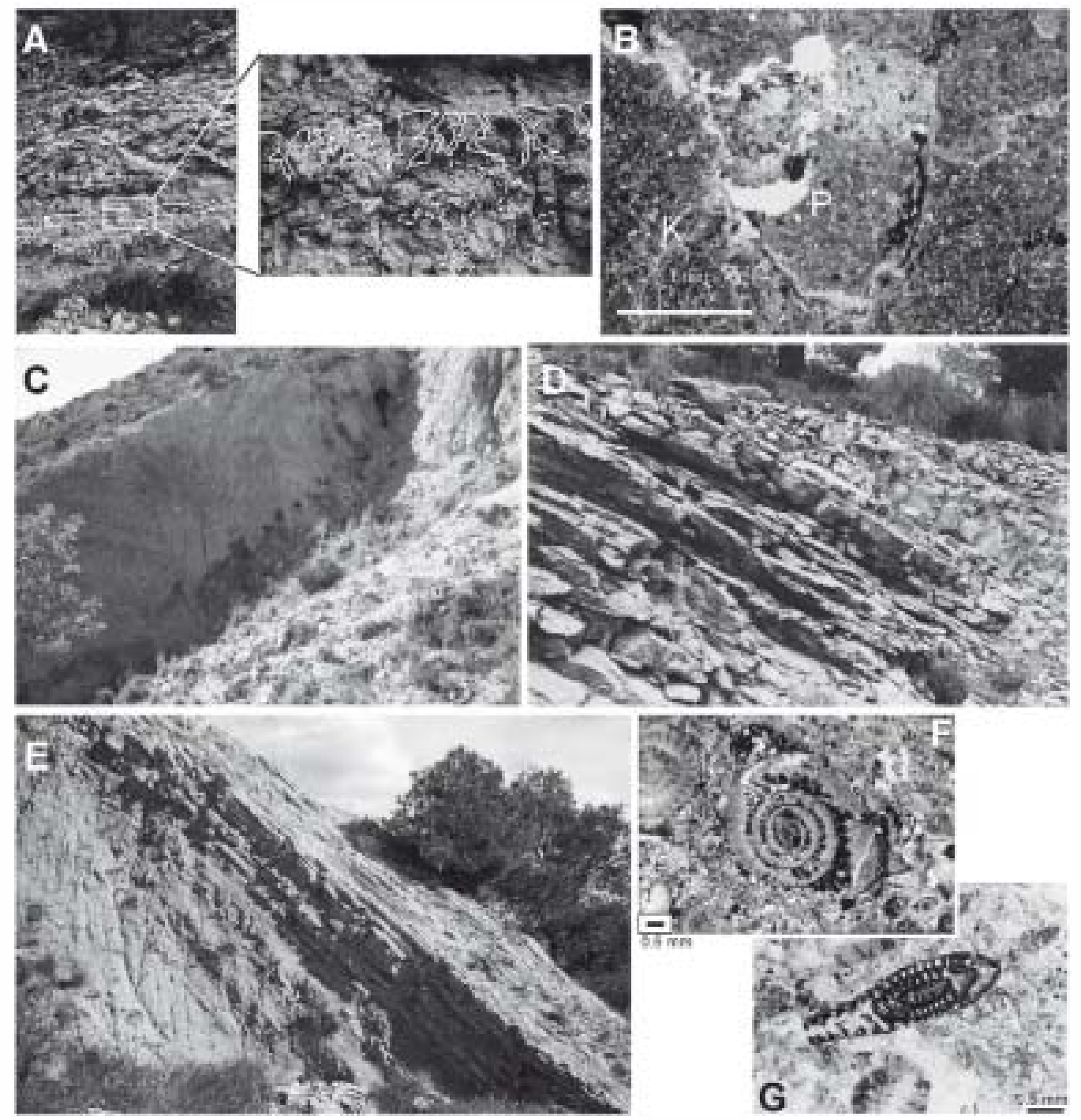

Fig. 8. A) Field aspect of the Maastrichtian-Danian hardground in Sierra del Carche (Carche section) separating the top of EBSU-3 (Raspay Fm) from the limestones of EBSU-4 (AlberquillaFm). Note the large Thalassin aides burrows at the top of EBSU-3. B) Microphotograph of a thin section of the same hardground, showing micro stromatolitic lamination, enriched in phosphates. C, $\mathbf{D}$ and E) Field aspects of EBSU-4 in (C) the Agost section (Agost Fm); (D) Carche section (Alberquilla Fm); and (E) Alfaz del Pi section (Agost Fm). F-G) Microscopy images of diagnostic large benthic foraminifera in EBSU-4 (Alberquilla Fm). F) Nummulites catari. G) Hottingerin lukasi.

According to Serra-Kiel et al. (1998), SBZ 2 is Selandian in age, SBZ 3 is late Selandian to early Thanetian, and SBZ 4 is late Thanetian. The lowermest part of the unit, containing very few large benthic foraminifera, was dated by means of planktonic foraminifera. According to these fossils, the age of the base is early (but not basal) Danian. The unit rests unconformably on the hardground developed at the top of the Raspay Fm.

The Agest Fm, which øutcreps in the central and southern areas, averages $15 \mathrm{~m}$ thick and mainly cønsists $\bullet$ red to green marls (Fig. 8C) rich in planktonic and small benthic foraminifera, ostracods and echinoid remains. The Fm alse shows fine intercalations of greenish to greyish marly wackestones, particularly in its lewer and upper part (Fig. 8E). These materials were depesited in hemipelagic environments receiving high amounts of clays. Based on the rich benthic foraminifer assemblage (including Bulimina trinitatensis Cushman and Jarvis, 1928; C. velascoensis Cushman, 1925; Gyroidinoides globosus Hagenow, 1842 and Nuttallides truempyi Nuttall, 1930, amøng others), a bathyal water-depth deeper than $500 \mathrm{~m}$ was calculated for these depesits (Agest, Caravaca), according to the estimates of Berggren 
and Aubert (1983) and Van Morkhoven et al. (1986). These environments, dominated by low energy settings, suffered sporadic turbidity currents (represented by finely laminated, sandy packstones, mainly in the lower part of the unit) or debris flows (Alfaz del Pi).

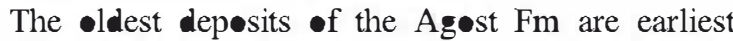
Danian in age. Age dating is based on the most complete sections (Agest and Caravaca), where the first biezene -f planktonic foraminifers of the Palaeocene has been identified (e.g.: Canude et al., 1991; Parde et al., 1996; Molina et al., 1996, 2005). The top of the unit is intensely diachrøn given it is usually capped by an eresive surface. In Caravaca, where this eresive surface is absent, a Globanomalina pseudomenardii Zøne identified at the top of the unit (Pujalte et al., 1994) indicates a Thanetian age. In the Aixorta region, the deposits corresponding to this time-interval are represented by a condensed sequence, for which depesitional rates lower than $0.5 \mathrm{~mm} / 1000$ years were calculated. Bored hard grounds and open marine stromat litic crusts with abundant entrapped planktonic foraminifera are the most typical features of this sequence.

\subsection{Late Thanetian event}

In the late Thanetian, a regional tectonic episede -nce again caused rapid changes in basin geometry and prepare the new tectonosedimentary setting in which the depesition of EBSU-5 would take place. This event, marked by an unconformity in the whole area, defines a major regional change in the sedimentary conditions. These started to be controlled by turbidity currents, which affected most of the area examined.

The event is recorded in the Carche section by a highly burrowed surface at the top of the Alberquilla Fm. This surface marked the end of the development of the reefal complex and the onset of mixed sedimentation - f marls and turbidites (Pinøs• Fm, see beløw). In the Aix $\bullet$ rta zone, the event is recorded by the generation of an $\bullet$ list lithic unit, which includes large slumps and bøulders of latest Cretaceous-Palaeøcene age (Fig. 9A, B). In ๑ther areas, like Maigmó and Aspe, the event implied intense erøsiøn, which eliminated part or all $\bullet$ the Agøst Fm (Palaeøcene) and even part of the Raspay Fm (Upper Maastrichtian), before the depesition of EBSU-5 had started (Fig. 3). Basinwards in Caravaca, ne substantial eresion eccurred, and the event is marked by a rapid increase in the influx of turbidites.

The age of the event is herein considered as late Thanetian. The youngest depesits below the unconformity found in Caravaca, are late Thanetian ( $G$. pseudomenardii Zøne sensu Pujalte et al., 1994, a zøne equivalent te $\mathrm{P} 4 \mathrm{a}$ and $\mathrm{P} 4 \mathrm{~b}$ in Berggren and Norris, 1997), whilst the depesits abøve it are early Ilerdian (the term Ilerdian is used here in the sense of Hottinger and Schaub, 1960 and Orue-Etxebarría et al., 2001). In the Carche section, these deposits correspond to the Shallow Benthic Zøne 5 (sensu Serra-Kiel et al., 1998) and, in the rest of the study area, to the Acarininasoldadoensis Zøne (following the biøzonation by Pujalte et al., 1994, a zøne equivalent to zones P4c and P5 in Berggren and Norris, 1997).

\subsection{EBSU-5 (uppermost Thanetian to lower Ypresian)}

After the late Thanetian event, sedimentation in most -f the area became dominated by outer platform to hemipelagic conditions, strongly influenced by turbidite prøcesses. The result is a heter lithic røck unit $\bullet$ variable

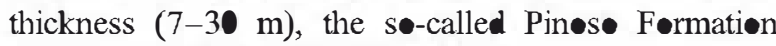
(Chacón and Martín-Chivelet, 2005b), formed by green to -chre marls altemating with $\bullet c h r e$, often laminated, sandy packstones to grainstones $\bullet$ furbiditic origin (Fig. 9C, D).

These marls yield rich assemblages of planktonic and

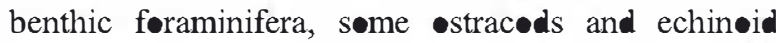
remains, whilst the sandy limestones show considerable mixing with faunal debris. These mixtures include remnants of shallow and deeper biota (fragments of

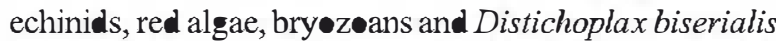
(incertae sedis), an abundance of large benthic foraminifera, some small benthic foraminifera, ostracods and scarce planktonic foraminifera) that show different degrees of sedimentary reworking (Fig. 9E, F).

The age of EBSU 5 is latest Thanetian to early Ypresian (i.e., middle Ilerdian in the sense of Hottinger and Schaub, 1960; Orue-E ebarría et al., 2001), based on the study of non-reworked, large benthic foraminifera in the Carche section. These foraminifers led to the identification of SBZ 5 (sensu Serra-Kiel et al., 1998; Chacón, 2002) as well as planktonic foraminifera from -ther sections (Aspe, Caravaca), characterising the $A$. soldadoensis Zone and the lower part of the Morozovella subbotinae Zøne (equivalent to P6 in Berggren and Norris, 1997).

Althøugh EBSU-5 reflects substantial regiønal hømogenisation of the depesitional conditions, in søme basinward areas (Aguas de Busøt), sedimentation is represented by open marine, red coløured, intensely burrowed, condensed carbonate hemipelagic deposits formed at bathyal depths (Chacón, 2002).

\subsection{Intra-Ypresian event}

Within the Ypresian, the last of the main tectonic episødes took place, leading to the re-organization of 

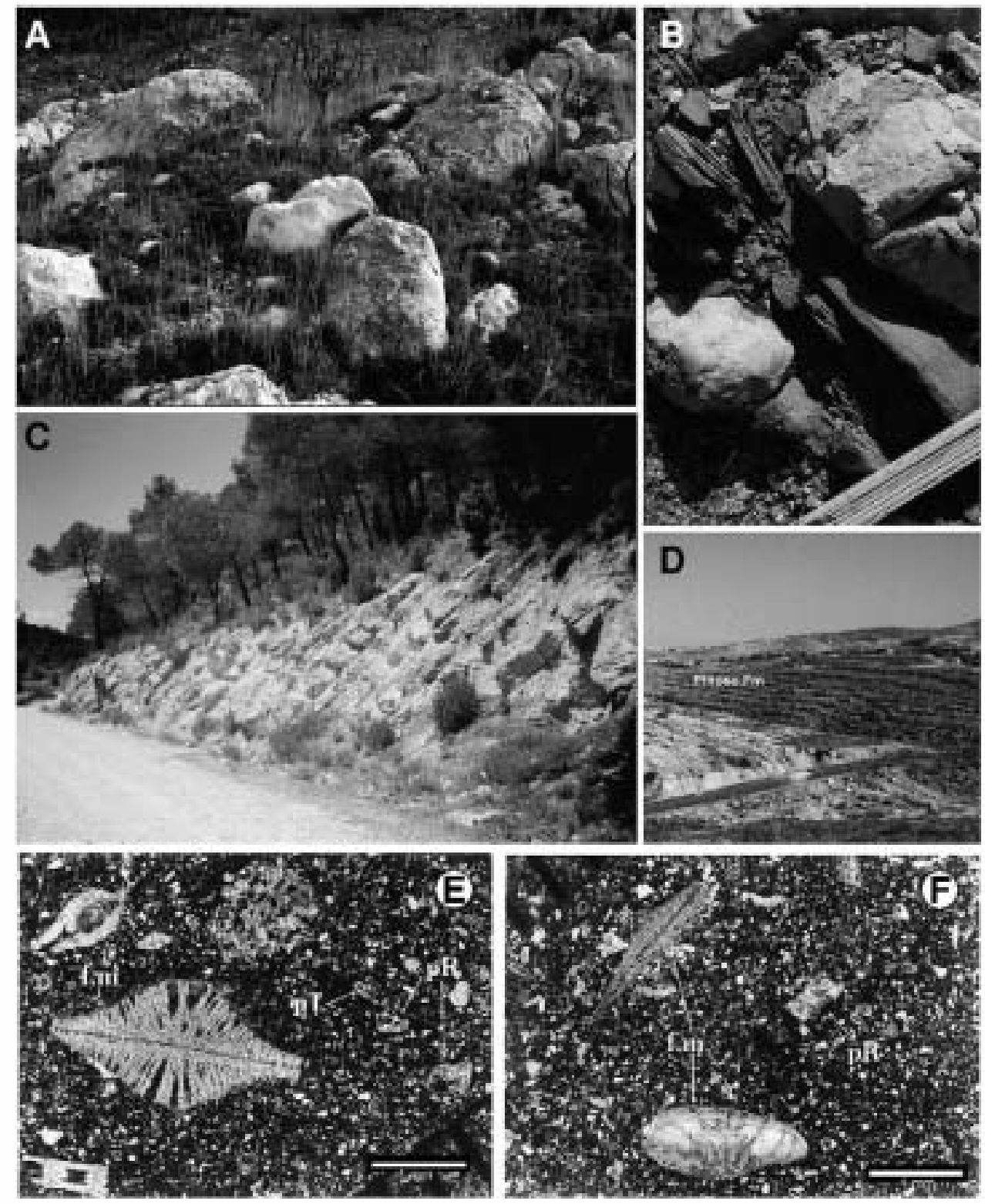

Fig. 9. A) Field aspect of the latest Thanetian event in the Aixorta section, marked by chaotic deposits that include large boulders from the latest Cretaceous limestones (sometimes showing the development of a latest Maastrichtian-Palaeocene hardground). B) Detail of the chaotic bed, showing limestone boulders of latest Cretaceous age embedded in and mixed with late Thanetian dark calcarenites, rich in siliciclastics. C and $\mathbf{D})$ Field views of EBSU-5 (Pinoso Fm) in Sierra del Carche (C) and Aspe (D). E and F) Two aspects of microf acies of EBSU-5 showing a noticeable mixture of remains of faunas from different environments and ages. Key: f.m.: large benthic foraminifera; p.T.: Tertiary planktonic foraminifera; p.R.: Cretaceous planktonic foraminifera (reworked).

sedimentary envireranents. This meant a change in the sedimentary conditions, although they continued to be relatively homøgeneous across the whole area. This event marked the end of EBSU-5 depesition and is recorded by a regienal uncenformity.

In the north-westernmest area (Carche), the marls and sandy limestones of the Pines॰ Fm are limited at the top by an eresive surface, $\bullet$ ver which green marls, very rich in planktonic and micro-benthic foraminifera, bivalves and fragments of echinids, unconformably rest. In the Maigmó area, sedimentation after the tectonic event is als represented by green marls but, in this area, marls include many thick intercalations of limestones and marly limestones, showing numerøus slump structures and some calcarenite and laminated limestone beds of turbiditic origin, very rich in macr -benthic foraminifers. 
In the Jijena-Torremanzanas area, the Raspay Fm Maastrichtian depesits are directly covered by Eocene beige to green marls, yielding a rich asseciation of planktonic and micro-benthic foraminifers. Towards the top, these marls altemate with increasingly more numerous and thicker beige marly limestones beds, with abundant nummulitids and milielids.

We know the event took place within the Ypresian, since the youngest deposits below the unconformity, found in Aspe, are early Ypresian (M. subbotinae Zøne; P6a Zøne of Berggren and Norris, 1997), and the •ldest deposits resting over the unconformity have been dated as latest Ypresian (P9 Zøne of planktønic foraminifera described by Berggren and Norris, 1997).

5. Factors controlling stratigraphic units and regional events

The events and genetic units (EBSUs) described in the previous section outline the development of the hemipelagic settings of the ancient southern continental margin $\bullet$ Iberia during the end of the Mesøzic and start of the Cenøzoic, i.e., the time interval in which this basin changed from a passive continental margin to a convergent $\bullet$ ne. In this section, the origins of these events and the sedimentary patterns marked by the EBSUs are discussed in the evolutionary framework of the sedimentary basin and the Iberian plate (Fig. 10).

During mid Cretaceous times, Iberia formed a triangle-shaped microplate between Africa and Europe. This microplate was bøunded by: the Bay of Biscay's sea-fleor spreading axis and its continuation inte the North Pyrenean Fault Zone to the north; by the North Atlantic sea-fleor spreading axis to the west; and by the Azores and Alboran Facture Zones to the south and southeast (Fig. 1) (e.g., Ziegler, 1988). Southeastwards frøm this last boundary and partly detached from Africa, was the tectonically mobile, continental block of Alboran-Kabilias. This bleck was to be crucial in the subsequent evolution of the Betic margin, and part of it today comprises the Internal Zone of the Betic Chain.

The continental part of Iberia was then surrounded by the Pyrenean and Basque-Cantabrian basins to the north, the Lusitanian passive margin to the west and the South Iberian continental (or Betic) margin to the southsoutheast. This last margin was the outcome of the break-up and •blique divergence of Africa and Iberia

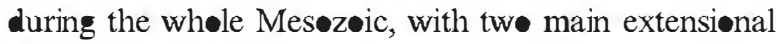
phases during early Jurassic and early Cretaceous times (GarcíaHernández et al., 1980; Ziegler, 1988; Vera, 1988, 2001; Vilas et al., 2001). Following the second extensional phase, the basin reached its maximum extension.
This eccurred during a period of thermal subsidence in the mid Cretaceous (Martín-Chivelet, 1996). After this, the basin entere a complex evolutionary precess that precluded its transformation inte a convergent margin (e.g., Martín-Chivelet, 1996; Martín-Chivelet et al., 2002). This precess was the response to convergence between Africa and Eurasia, which culminated in the Miocene with the head-on continental collision between Africa and Iberia and the formation of the Betic-Rif -regenic belt (e.g., Ziegler, 1988; Dewey et al., 1989).

The sedimentary sequences examined here began their development after a period of regional tectonic activity, which took place in the late Cenomanian and Turonian. Tectonism gave rise to new listric faults (or reactivated pre-existing ones) in the Betic margin and induced abrupt topographic changes in the basin, all related to changes in the intraplate stresses of Iberia (De Ruig, 1992; MartínChivelet, 1992, 1996; Martín-Chivelet et al., 2002). At that time, Iberia moved independently, rotating counterclockwise relative to Europe in response to sinistral, transtensional, movements eccurring between Africa and Eurøpe (e.g., Savostin et al., 1986; Ziegler, 1988), and seafleor spreading took place along the axes established from Aptian times in the Bay of Biscay and the North Atlantic (Fig. 10). During the middle Cenomanian to late Turønian interval, the Bay of Biscay $\bullet$ cean axis spreading rate increased, determining an extended, multiphase rise in subsidence at the Basque-Cantabrian margin (e.g., Gräfe, 1994, 2005), and generalized tilting of the Iberian continental massif towards the northwest (e.g., García et al., 1985; Fløquet, 1991; Martín-Chivelet and Giménez, 1993; Aløns• et al., 1993; Wallrabe-Adams et al., 2005). Simultaneously, at the southern plate boundary (Albøran Fault Zøne), pøssibly the first transpressional-compressional movements occurred, as revealed by the short phase of low temperature-high pressure metamorphism that took place in the Alboran-Kabilias block around $91 \mathrm{Ma}$ (De Jong, 1990; Kuhnt and Obert, 1991; Puga et al., 2002).

In the study area, the end of the phase of tectonic activity corresponds to the Coniacian, coinciding with the "88.5 Ma extensional tectonic event" described for the Prebetic platform by Martín-Chivelet (1996). Upper Coniacian and Santonian depesits, under conditions of relative tectonic quiescence, sealed the former listric faults, and covered all the area, except for the inherited topegraphic highs. These aspects, along with the høm॰geneity of facies, suggest substantial relaxation -f previous tectonic stresses.

The late Coniacian to early late Santonian was, in fact, an interval of moderate but generalized subsidence in nearly all the basins of Iberia (Fig. 10) (e.g., Fløquet, 


\section{| "HEMIPELAGIC PREBETIC" (this paper)}

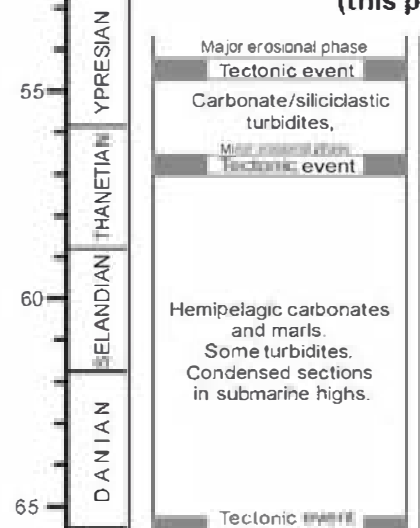

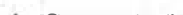
ctonic unies global K.T vioevent)

Hemipelagic marls, turbidites, slumps.

Tectonic event

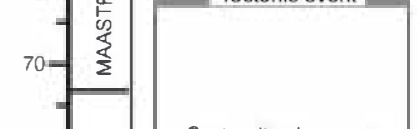

Contourites become more abundant

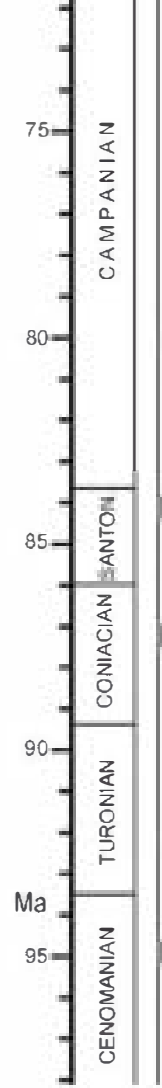

Hemıpelagic carbonates Variable siliciclastic influx Contomite development. tectonic quiescence

Teclonic event

Hemipelagic carbonates with intemal disconlinuities Hardgrounds on

submanne highs Franja anómala emerged

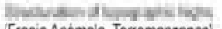
Franja Anómala, Torremanzanas Major unconformity

Wide carbonate platforms (external, hemipelagic) Sharp accsleration

"PREBETIC

PLATFORM"

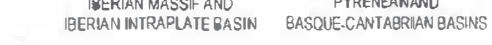

No stratigraphic recerd

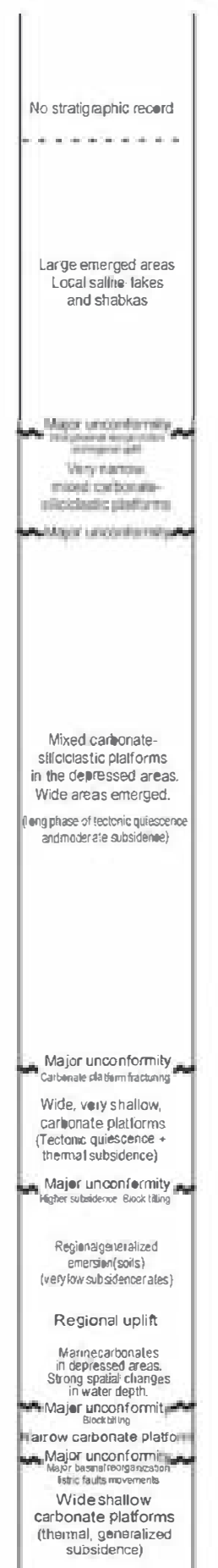
tectonics

Strong basinal reorganization, block movements
olistholiths. Low subsidence

Strong basinal Inverse faults. olistoliths

Long phase of relative

Strong basinal reorganization Block movements

Tectonic quiescence

Acceleration of subsidence and block tilting

phase or basin inversin (
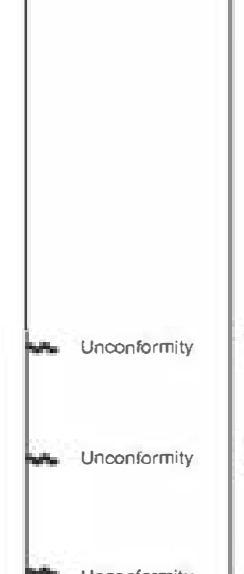

Strong, multiepisodic basinal reorganization Generalion or reactivalion of listric fautts.

Strong basinal reorganization

Fig. 10. Summary of the main palaeogeographic changes and evolutionary episodes identified in the study area (Hemipelagic Prebetic) for the late Cretaceous-early Palaeogene interval. Correlation of these episodes with the shallow areas of the same continental margin (Prebetic Platforn) and with other basins of Iberia, and integrating the evolution of the continental margin in the geodynamic framework of the relative motions of AfricaIberia-Europe. Details and references in the text. Time scale after Gradstein et al. (2004). 
1991; Gräfe, 1994; Martín-Chivelet, 1996; Gräfe, 1999; Reicherter and Pletsch, 2000; Vilas et al., 2003), characterize by the continuation, or re-establishment, - f wide carbonate platforms in shallew basin areas. In the Basque-Cantabrian, Pyrenean and Iberian Basins, majør stratigraphic uncenformities separate $\bullet$ lder depesits from the Coniacian-Santonian platforms (e.g., Fløquet, 1991; Gräfe, 1994; Gräfe et al., 2002; Berastegui et al., 2002), which could be related the slowing down of seafloor spreading rates in the Bay of Biscay and transtensional movements eccurring between northern Iberia and Eurøpe (Gräfe et al., 2002; Flequet, 2004). It is remarkable that, during this interval -f relaxation of intraplate stresses in the søuthern half of Iberia, the Basque-Cantabrian and Betic margins, became connected via the Iberian intracentinental basin, which acted as a shalløw seaway (Aløns• et al., 1993).

In the study area, the Coniacian-Santonian interval of relative tectonic quiescence ended around $84 \mathrm{Ma}$, when the intra-late Santonian event took place. This event, which caused changes in basin geometry, palae^ge graphy and subsidence patterns, has been described to have had similar consequences in ther areas $\bullet$ the continental margin, such as the Prebetic platform (where the event is considered as latest Santonian to earliest Campanian in age, Martín-Chivelet, 1996; Martín-Chivelet et al., 1997; Vilas et al., 2003), and the pelagic domains of the Subbetic (Reicherter and Pletsch, 2000). In general, abrupt bleck movements and a substantial slowing down of regional subsidence took place. Along with a generalized increase in terrigenous influx and rapid, tectonically induced regression in the Prebetic platform, these factors strongly suggest a compressional origin for the event. This interpretation is in agreement with the changes that were taking place in Iberia and its plate boundaries.

At that time, major plate reorganization occurred between Europe and Africa, causing the end of the countercløckwise rotation of Iberia relative to Eurøpe (Srivastava et al., 1990) and the onset of AfricanEuropean convergence (e.g., Savostin et al., 1986). Iberia, which had moved independently since the Aptian, then became attached to Africa (Maldonade et al., 1999). All these phenomena induced drastic changes in the basins of Iberia (Fig. 10). In the North, seafloor spreading in the Bay of Biscay finished before chrøn 34 (latest Santenian, $84 \mathrm{Ma}$ ) (Bøilløt and Malød, 1988; Srivastava et al., 1990; Olivet, 1996). Alse, extensional velcanism (which lasted since the Albian) in the Basque-Cantabrian region came to an end (Castañares et al., 201), and the first thrust-sheets were emplaced in the central-eastern Pyrenees (Puigdefábregas and Souquet, 1986). Moreover, a generalized uplift affected the central part of Iberia, accompanied by majør marine regressions (Fløquet, 1991; Aløns• et al., 1993; García et al., 2004; Fløquet, 2004). As a consequence, the marine connection that existed between the BasqueCantabrian and the Betic margin across the Iberian seaway was definitively cut. In contrast, African-Eurøpean convergence proveked a stage of penetrative deformation in the Alboran-Kabilias bleck (cf. Wildi, 1983; Dewey et al., 1989; De Jøng, 1990; cf. Puga et al., 2002).

During the Campanian and early Maastrichtian interval, sedimentation took place in the Betic margin in a setting of moderate subsidence, shallower conditions and certain tectonic instability. Block mevements and plate adjustments configured a new $\bullet$ cean $\bullet$ graphic pattern in the hemipelagic settings, allowing the deposition of cøntourites (bøttom-current reworked hemipelagites). The sea floor became affected by deep ecean currents, probably because of its location in the northem boundary -f the progressively narrower $\bullet$ ceanic passage between Africa and Iberia, through which the equatorial current system flowed in the westemmost area of the Tethys Seaway (Martín-Chivelet et al., 2003).

Sedimentation prevailed until the "mid" Maastrichtian, when the event that $\bullet c c u r r e d$ around the early to late Maastrichtian transition not only caused major changes in sedimentation but gave rise to the first unequivecal compressional deformations found in the study area. These are reflected in inverse faults and in the

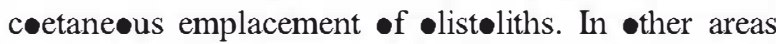
-f the Prebetic as well as in the Subbetic, the event has als been identified. In the former, it marks an abrupt change in the evelution of the shallow platforms (MartínChivelet, 1995), whereas in the Subbetic, rapid deepening of pelagic domains took place (Chacón, 2002). There, contourite depesits become replace by a sedimentation dominated by marls, in which the presence of turbidites and other gravitational depesits is not uncommon. The simultaneous uplift of the shallow areas and sinking of the deeper ones could als be evidence - on a lithospheric scale - of compression, possibly reflecting the vertical lithøspheric motions of a basin flank affected by tectonic contraction. Numerical models indicate that when a continental margin is subjected to compression, the peripheral bulge flanking the basin can be magnified, resulting in uplift $\bullet$ the basin flanks and seaward migration of the shereline (Cløetingh, 1988). Simultaneously, the basin centre deepens, leading to a steeper slope.

The 'mid' Maastrichtian event can be correlated with the major palaengeographic changes eccurring in the northern areas of Iberia, bøth in the Basque-Cantabrian 
and the Pyrenean basins (Puigdefábregas and Souquet, 1986; Fløquet, 1991; Deramond et al., 1993; Baceta et al., 2004; Flequet, 2004) in response to continued North-South convergence and transpression (Fig. 10). Siliciclastic input notably increased in all basins, prbably reflecting the uplift and eresion of central Iberia. Similar compressional episedes have been reported in the Maastrichtian of different locations of northern Africa (e.g., Chøtin et al., 2000; Ait Brahim et al., 2002).

The tectonic event in the study area during the Cretaceus-Palaeogene transition caused envirømental and palaengengraphical changes related the gløbal $\mathrm{KP}$ mass-extinction. These changes have alse been detected in the Prebetic platform, where vertical lithospheric movements, generalized uplift and rapid transgression -ccurred towards the end of the late Maastrichtian (Martín-Chivelet, 1992). These processes led to the formation of small basins that were lately filled with evaporites (Fourcade, 1970). For the Subbetic, Vera et al. (2003) described a rapid bathymetric change in the pelagic environment, and depesition, during the Danian to earliest Selandian, of massive accumulations of calcarenites bearing Microcodium clasts from emerged areas. Thrøughøut the Betic margin, regional tectønism induced rapid differential subsidence. Again, we find shallower areas of uplift and basin centre deepening, probably reflecting the lithospheric motions of a basin flank subjected to compressional episodes (Cløetingh, 1988).

The rest of Iberia and Northern Africa were alsø characterized by compressional tectonics at this time (e.g., Andeweg, 2002), although most of the studies examining different basins fell short of the temporal or spatial accuracy necessary to establish precise correlations. Across the Pyrenean and Basque-Cantabrian basins, inversion of former Mesøzoic normal faults -ccurred, and subduction or underthrusting was active. Within this compressional setting, however, a period of relative quiescence started around the KP boundary in the Pyrenees, which would last until the end of the Palaecene or earliest Eocene (e.g., Pujalte et al., 2000; Orue-Exebarría et al., 2001; Baceta et al., 2004) and which was accompanied by very løw rates of tectonic shortening (Vergès and García-Senz, 2001).

The late Thanetian event recognized in the study area represents a regienal tectonic pulse that caused erosive phenomena and/or a major changes in sedimentation, def ined by the installation of relatively shallow turbiditic systems. De Ruig (1992) als• described rapid platform emergence, block-faulting, and tectonic steeping of the continental sløpe in the margin. All these features strongly suggest a contractional origin for this event. Its correlation with other parts of the continental margin as well as with -ther basins of Iberia and surrounding areas is, nevertheless difficult, probably because of the lack of accurate studies and precise age-dating. The exception is the Pyrenees (Fig. 10), where Palaecene-Eøcene marine successions are exceptionally developed and exposed. Here, a regional tectonic event marked the end of the period of tectonic quiescence mentioned above. This event, identified by several authors, has been recently dated as latest Thanetian (lower Ilerdian) by OrueE barnía et al. (2001).

Finally, the intra-Ypresian event, which marks the end of the time-span considered in this paper, represented a major event in the evolution of the study area and rest of the Betic margin. This event, which invelved deformational structures and a main erosive stage in the Prebetic area (De Ruig, 1992; Geel et al., 1998), marked a sharp acceleration of compressiønal movements. Majør changes in depesitional systems and subsidence have als• been described in the Subbetic, where the local emplacement of -listostrømic units started to take place (Cømas, 1978; Vera, 2004). This acceleration in compressional regime has alsø been reported for the Intemal Betics (e.g., MartínAlgarra, 2004), where a phase $\bullet$ high pressure metamorphism started (Puga et al., 2002). Beyond the Betics, the tectonic episode has been described for many places of Iberia and the western Mediterranean area, indicating the bread reorganization of African-Eurøpean relative motions (e.g., Ziegler, 1988; Dewey et al., 1989). Remarkably, in the Pyrenees, this time coincided with the onset of the main orøgenic phase (Puigdefábregas and Souquet, 1986; Vergès and García-Senz, 2001; Muñøz, 2002), and, in the interior of Iberia, the major basin inversions commenced (e.g., Álvar et al., 1979; Guimerà and Álvare, 1989; Guimerà et al., 1995; Salas et al., 2001), linked to the transmission of stresses frøm the northern and southern plate margins.

\section{Conclusions and summary}

Herein, we examine the upper Cretaceous to lower Eocene hemipelagic successions exposed in the Eastern Prebetic Zone (SE Spain), in an effort to document the development of the ancient southern continental margin $\bullet$ Iberia during its transition frøm a passive margin t• a convergent $\bullet$. The long-term stratigraphy $\bullet$ these successions is punctuated by six regional events, showing abrupt changes in palaenge graphy, envirømental conditions and sedimentary facies, as well as significant depositional gaps, variations in sedimentation rates, and enhanced synsedimentary tectonics. Collectively, they suggest important reconfigurations of the basin's architecture that took place at time intervals notably shorter 
than the chron biestratigraphy is able to reselve. The ages -f these six events, determined by planktonic foraminifera biostratigraphy, are: intra-Coniacian, late Santonian, "mid" Maastrichtian, latest Maastrichtian-earliest Danian, late Thanetian and intra-Ypresian.

The events are tectonic in origin. Each one caused abrupt changes in lecal and regienal subsidence and rapid differential block movements, configuring a new scenari॰ for sedimentation. The sedimentary systems that devel-ped under each scenari॰ are grouped int genetic units bounded by event horizons, herein denoted "event bøunded stratigraphic units" (EBSUs). Frøm a regienal perspective, by identifying and characterizing these EBSUs, a detailed chronestratigraphic framework can be inferred for the Betic continental margin, from shallow to deep sequences, on which to base further studies.

Through tectonesedimentary characterization of the events and correlations with both, the adjacent shallow marine sequences of the Prebetic platform and the basin pelagites of the Subbetic, each EBSU (but the first) was interpreted as induced by contractional tectonics. Besides, comparisens with other basins of Iberia and Northem Africa allowed us to consider the development of the Betic margin within the framework of the geodynamic evolution of the western Tethys, and to explain the events as the result of changes in intraplate stresses related to relative movements between Africa, Eurøpe and Iberia.

Frøm a methedelegical standpøint, this work shows the enormous potential of event stratigraphy for analysing large sedimentary basins and making extrabasin correlations.

\section{Acknowledgements}

This paper is a contribution to project CGL200506636-C2 of the Spanish Ministry of Education and Science, and to the UCM-CAM Research Groups 910429 (Basin Analysis) and 910198 (Paleøclimat•løgy and Gløbal Change). Dr. B. Chacón enjeys a pøstdectoral stay at Bremen University supported by the Spanish Ministry of Education and Science. We are grateful t• Dr. L. Vilas (U. Cømplutense) for cønstructive comments $\bullet$ the first draft of the manuscript and A. Burton for English edition. The paper alsø benefited from reviews from tw॰ an॰nymous referees and Editor Bruce W. Sellweod.

\section{References}

Ait Brahim, L., Chotin, P., Hinaj, S., Abdelouaf, A., El Adraoui, A., Nakcha, C., Dhont, D., Charroud, M., Sossey Alaoui, F., Amrhar, M., Bouaza, A., Tabyaoui, H., Chaouni, A., 2002. Paleostress evolution in the Moroccan African margin from Triassic to Present. Tectonophysics 357, 187-205

Alonso, A., Floquet, M., Mas, R., Meléndez, A., 1993. Late Cretaceous carbonate platforms: origin and evolution, Iberian Range, Spain. In: Simó, J.A.T., Scott, R.W., Masse, J.P. (Eds.), Cremeous Carbonate Platforms. American Association of Peroleum Geologists Memoir, vol. 56, pp. 297-313.

Álvaro, M., Capote, R., Vegas, R., 1979. Un modelo de evolución geotectónica para la Cadena Celtibérica. Acta Geologica Hispanica $14,172-178$.

Andeweg, B., 2002. Cenozoic tectonic evolution of the Iberian Peninsula, causes and effects of changing stress frelds. Ph.D. Thesis, 178 pp. Vrije Universiteit Amsterdam.

Arz, J.A., Arenillas, I., Molina, E., Sepúlveda, R., 2000. La estabilidad evolutiva de los foraminíferos planctónicos en el Maastrichtiense superior y su extinción en el límite Creńcico/Terciario de Caravaca, España. Revista Geológica de Chile 27 (1), 27-47.

Azema, J., Foucault, A., Fourcade, E., García Hemández, M., González Donoso, J.M., Linares, A., Linares, D., López Garrido, A.C., Rivas, P, Vera, J.A., 1979. Las microfacies del Jurásico y Cretácico de las Zonas Externas de las Cordilleras Béticas. Universidad de Granada. 83 pp.

Baceta, J.I., Pujalte, V., Serra-Kiel, J., Robador, A., Orue-Etxebarria, X., 2004. El Maastrichtiense final, Paleoceno e Ilerdiense inferior de la CordilleraPirenaica. In: Vera, J.A. (Ed.), Geología de España. SGE-IGME, Madrid, pp. 308-320.

Berastegui, X., Caus, E., Puig, C., 2002. Pyrenees. In: Gibbons, W., Moreno, T. (Eds.), Geology of Spain. Geological Society of London, London, pp. 265-272.

Berggren, W.A., Aubert, J., 1983. Paleogene benthonic foraminiferal biostratigraphy and bathymery of the Central Coast Ranges of Califomia. In: Brabb, E.E. (Ed.), Studies in Tertiary Stratigraphy of the Califomia Coast Ranges. United States Geological Survey, Prof. Paper, vol. 1213, pp. 4-21

Berggren, W.A., Norris, R.D., 1997. Biostratigraphy, phylogeny and systematics of Paleocene rochospiral planktic foraminifera. Micropaleontology 43 (suppl. 1) $116 \mathrm{pp}$

Boillot, G., Malod, J., 1988. The North and Northwestern Spanish Continental Margin: a review. Revista de la Sociedad Geológica de España 1, 295-316.

Canudo, J.I., Keller, G., Molina, E., 1991. Cretaceous-Tertiary boundary extinction pattern and faunal tumover at Agost and Caravaca, SE Spain. Marine Micropaleontology 17, 319-341.

Canudo, J.I., Keller, G., Molina, E., Ortiz, N., 1995. Planktic foraminiferal tumover and $\mathrm{\alpha} 13 \mathrm{C}$ isotopes across the PaleoceneEocene ransition at Caravaca and Zumaya, Spain. Palaeogeography, Palaeoclimatology, Palaeoecology 114, 75-100.

Castañares, L.M., Robles, S., Gimeno, D., Vicente-Bravo, J.C., 2001. The submarine volcanic system of the Errigoiti Formation (Albian-Santonian of the Basque-Cantabrian basin, northern Spain): stratigraphic framework, facies and sequences. Journal of Sedimentary Research 71, 318-333.

Chacón, B., 2002. Las sucesiones hemipelágicas del final del Cretácico e inicio del Paleógeno en el SE de la Placa Ibérica: Estratigrafía de eventos y evolución de la cuenca, Ph.D. Thesis. Universidad Complutense, Madrid, $439 \mathrm{p}$.

Chacón, B., Martín Chivelet, J., 1999. El Créńcico terminal y Paleoceno de la Sierra del Carche (Dominio Prebético, Jumilla). Caracterización estratigráfica y sedimentológica. Geogaceta 26, 11-14.

Chacón, B ., Martín-Chivelet, J ., 200la. Inplicaciones tectosedimentarias de la discontinuidad estratigráfica del Maastrichtiense medio en Aspe (Prebético de Alicante). Revista de la Sociedad Geológica de España 14 (1-2), 123-133. 
Chacón, B., Martín-Chivelet, J., 2001b. Discontinuidades y confornidades correlativas en las series hemipelágicas del final del Cretácico en el Prebético, Caracterización biocronoestratigráfica. Geo-Temas 3 (2), 177-180.

Chacón, B., Martín-Chivelet, J., 2003. Discontinuidades estratigráficas regionales en las series hemipelágicas finicretácicas del Prebético (sector Jumilla - Callosa - Aspe). Joumal of Iberian Geology 29, 89-108.

Chacón, B., Martín-Chivelet, J., 2005a. Major palaeoenvinonmental changes in the Campanian to Palaeocene sequence of Caravaca (Subbetic zone, Spain). Joumal of Iberian Geology 31 (2), 299-310.

Chacón, B., Martín-Chivelet, J., 2005b. Subdivisión litoestratigráfica de las series hemipelágicas de edad Coniaciense - Thanetiense en el Prebético oriental (SE de España). Revista de la Sociedad Geológica de España 18 (1-2), 3-20

Chacón, B., Martín-Chivelet, J., Gräfe, K.-U., 2004. Latest Santonian to latest Maastrichtian planktic foraminifera and biostratigraphy of the hemipelagic series of the Prebetic (Murcia and Alicante provinces, SE Spain). Cretaceous Research 25, 585-601.

Chotin, P., Ait Brahim, L., Tabyaoui, H., 2000. The Southem Tethyan margin in Northeastem Morocco, sedimentary characteristics and tectonic control. In: Crasquin-Soleau, S., Barrier, E. (Eds.), PeriTethys Memoir 5: New Data on Peri-Tethyan Sedimentary Basins, Mémoires du Museum. National d'Histoire Naturelle, vol.1 82. Muséum National d'Historie Naturelle, Paris, pp. 107-128.

Cloetingh, S., 1988. In maplate stresses: a new element in basin analysis. In: Kleinspelın, K.L., Paola, C. (Eds.), New Perspectives in Basin Analysis. Springer-Verlag, NewYork, pp. 205-230.

Comas, M.C., 1978. Sobre la Geología de los Montes Orientales: sedimentación y evolución paleogeográfica desde el Jurásico hasta el Mioceno inferior (Zona Subbética, Andalucía). Ph. D. Thesis, Univ. País Vasco, Bilbao, $323 \mathrm{p}$

De Jong, K., 1990. Alpine tectonics and rotation pole evolution of Iberia. Tectonophysics $184,279-296$

De Ruig, M.J., 1992. Tectono-sedimentary evolution of the Prebetic fold belt of Alicante (SE Spain). Ph.D. Thesis. Free University Amsterdam, $207 \mathrm{p}$.

Deramond, J., Souquet, P., Fondecave-Wallez, M.J., Spetch, M., 1993. Relationshps between thrust tectonics and sequence stratigraphy surfaces in foredeeps: model and examples from the Pyrenees (Cretaceous-Eocene, France, Spain). In: Williams, G.D., Dobb, A. (Eds.), Tectonics and Seismic Sequence Stratigraphy. Geological Society Special Publication, vol. 71, pp. 193-219.

Dewey, J.F., Helman, M.L., Turco, E., Hutton, D.H.W., Knott, S.D., 1989. Kinematics of the Western Mediterranean. In: Coward, M.P., Dietrich, D., Park, R.G. (Eds.), Alpine Tectonics. Geological Society Special Publication, London, vol. 45, pp. 265-283.

Einsele, G., 1998. Event stratigraphy: recognition and interpretation of sedimentary event horizons. In: Doyle, P., Bennet, M.R. (Eds.), Unlocking the Stratigraphical Record: Advances in Modem Stratigraphy. Wiley, Chichester, England, pp. 145-193.

Einsele, G., Ricken, W., Seilacher, A. (Eds.), 1991. Cycles and Events in Sratigraphy. Springer-Verlag, Berlin. 955 pp.

Floquet, M., 1991. La plate-fonne nord-castillane au Crétacé supérieur (Espagne). Arrière-pays ibérique de la marge passive bascocantabrique. Sédimentation et Vie. Mémoires Géologiques de la Université de Dijon, 14, $925 \mathrm{p}$.

Floquet, M., 2004. El Cretácico superior de la Cuenca VascoCantábrica y áreas adyacentes. In: Vera, J.A. (Ed.), Geología de España. SGE-IGME, Madrid, pp. 299-306.

Fourcade, E., 1970. Le Jurassique et le Crétacé aux conf uns des Chaines Bétiques et Ibériques (Sud-Est de l'Espagne). Ph.D.Thesis, Univ. Paris, 2 vol., $427 \mathrm{p}$.
García, A., Giménez, R., Segura, M., 1985. Un modelo para la etapa 'proto-atlántica' del Cretácico medio en la Cordillera Ibérica Suroccidental. Estudios Geológicos 41, 21-206

García, A., Mas, R., Segura, M., Carenas, B., García-Hidalgo, J.F., Gil, J., Alonso, A., Aurell, M., Bádenas, B., Benito, M.I., Meléndez, A., Salas, R., 2004. Segunda fase de postifting: Cretácico Superior. In: Vera, J.A. (Ed.), Geologia de España. SGE-IGME, Madrid, pp. 509-522.

García Hemández, M., López Garrido, A.C., Sanz de Galdeano, C., Vera, J.A., Rivas, P., 1980. Mesozoic paleogeographic evolution in the Extemal Zones of the Betic Cordillera (Spain). Geologie en Mijnbouw 59, 155-168.

Geel, T., Roep, Th.B., Vail, P.R., Van Hinte, J., 1998. Eocene tectonosedimentary patterns in the Alicante region (Southeastern Spain). In: Handerbol, J., De Graciansky, P.-Ch., Jaquin, Th., Farley, M., Vail, P. (Eds.), Mesozoic-Cenozoic Sequence Stratigraphy of Westem European Basins. - Society for Economic Paleontologists and Mineralogists, Special Publication, vol. $6 \mathbf{0}$. SEPM, Tulsa OK, pp. 289-302.

Gradstein, F.M., Ogg, J.G., Smith, A.G., Agterberg, F.P., Bleeker, W., Cooper, R.A., Davydov, V., Gibbard, P., Hinnov, L., House, M.R., Lourens, L., Luterbacher, H-P., McArthur, J., Melchin, M.J., Robb, L.J., Shergold, J., Villeneuve, M., Wardlaw, B.R., Ali, J., Brinkhuis, H., Hilgen, F.J., Hooker, J., Howarth, R.J., Knoll, A.H., Laskar, J., Monechi, S., Powell, J., Plumb, K.A., Raffi, I., Röhl, U., Sanfilippo, A., Schmitz, B., Shackleton, N.J., Shields, G.A., Strauss, H., VanDam, J., Veizer, J., van Kolfschoten, Th., Wilson, D., 2004. A Geologic Time Scale 2004. Cambridge University Press. 589 pp.

Gräfe, K.U., 1994. Sequence stratigraphy in the Creceous and Paleogene (Aptian to Eocene) of the Basco-Can brian Basin (N. Spain). Tübinger Geowissenschaftliche Arbeiten, Reihe A, Band 18. Tübingen. $418 \mathrm{p}$.

Gräfe, K.U., 1999. Sedimentary cycles, burial history and foraminiferal indicators for systems racts and sequence boundaries in the Cretaceous of the Basco-Cantabrian Basin (Northem Spain). Neues Jahrbuch fir Geologie und Palaeontologie Abhandlungen $212,85-130$.

Gräfe, K.U., 2005. Late Cretaceous benthic foraminifers from the Basque-Cantabrian basin. Northem Spain. Joumal of Iberian Geology 31 (2), 277-298.

Gräfe, K.U., Floquet, M., Rosales, I., 2002. Late Creceus of the BasqueCan brian basin. In: Gibbons, W., Moreno, T. (Eds.), Geology of Spain. Geological Society of London, London, pp. 281-284.

Guimerá, J., Álvaro, M., 1989. Sructure et évolution de la compression alpine dans la chaîne ibérique et al chaîne cõtière catalane (Espagne). Bulletin de la Societé Géologique de la France 6 (2), 339-348.

Guimerá, J., Alonso, A., Mas, J.R., 1995. Inversion of an extensional ramp basin by a newly forned thrust: the Cameros basin (N Spain). In: Buchanan, J.G., Buchanan, P.G. (Eds.), Basin Inversion. Geological Society Special Publication, London, vol. 88, pp. 433-453.

Hoedemaeker, J., 1973. Olithos romes and other delapsional deposists, and their occurrence in the region of Moratalla (Prov. of Murcia, Spain). Scripta Geologica 19 (Leiden, 207 pp.).

Hottinger, L., Schaub, H., 1960. Zur stufeneninteilung des Paleocaens uns Eocaens: Einfiihnung der stufer Ilerdien und Biarritzien. Eclogae Geologicae Helvetiae 53, 454-479.

Kaiho, K., Lamolda, M.A., 1999. Catastrophic extinction of planktonic foraminifera at the Cretaceous-Tertiary boundary evidenced by ste isotopes and foraminiferal abundance at Caravaca, Spain. Geology $27,355-358$ 
Kulınt, W., Obert, D., 1991. Evolution crétacée de la marge tellienne Bulletin de la Société Géologique de France 162, 515-522.

Maldonado, A., Somoza, L., Pallarés, L., 1999. The Betic orogen and the Iberian-African boundary in the Gulf of Cadiz: geological evolution (cen North Atlantic). Marine Geology 155, 9-43.

Martín-Algarra, A. (Coord.) 2004. Zonas Intemas Béticas. In: Vera, J.A. (Ed.), Geología de España. SGE-IGME, Madrid, 395-437.

Martín-Chivelet, J., 1992. Las platannas carbonadas del Creńcico superior de la Margen Bética (Altiplano de Jumilla - Yecla, Murcia). Madrid. Ph.D.Thesis. Universidad Complutense, Madrid, 899 pp.

Martín-Chivelet, J., 1994. Litoes ratigrafia del Cretácico superior del Altiplano de Jumilla - Yecla (Zona Prebética). Cuademos de Geología Ibérica 18, 117-173.

Martín-Chivelet, J., 1995. Sequence stratigraphy of mixed carbonatesiliciclastic platforms developed in a tectonically active setting, upper Cretaceous, Betic continental margin (Spain). Journal of Sedimentary Research B65 (2), 235-254

Martín-Chivelet, J., 1996. Late Cretaceous subsidence history of the Betic Continental Margin (Jumilla-Yecla region, SE Spain). Tectonophysics 265, 191-211.

Martín-Chivelet, J., 2003. Quantitative analysis of accommodation patterns in carbonate platforns: an example from the mid-Creceous of SE Spain. Palaeogeography, Palaeoclimatology, Palaeoecology 200, 83-105.

Martín-Chivelet, J., Giménez, R., 1993. Évolutions sédimentaires et tectoniques des plates-fornes du sud-est de l'Espagne au cours $d u$ Cenomanien supérieur - Coniacien inférieur. Cretaceous Research $14,509-518$.

Martín-Chivelet, J., Giménez, R., Luperto-Sinni, E., 1997. La discontinuidad del Campaniense basal en el Prebético ¿Inicio de la convergencia alpina en la Margen Bética? Geogaceta 22, 121-124.

Martín-Chivelet, J., Berástegui, X., Rosales, I., Vera, J.A., Vilas, L., Caus, E., Gräfe, K.-U., Segura, M., Puig, C., Mas, R., Robles, S., Floquet, M., Quesada, S., Ruiz-Ortiz, P.A., Fregenal-Martinez, M.A., Salas, R., García, A., Martín-Algarra, A., Arias, C., Meléndez, N., Chacón, B., Molina, J.M., Sanz, J.L., Castro, J.M., García-Hemández, M., Carenas, B., García-Hidalgo, J., Gil, J., Ortega, F., 2002. Cretaceous. In: Gibbons, W., Moreno, T. (Eds.), Geology of Spain. Geological Society of London, London, pp. 255-292.

Martín-Chivelet, J., Fregenal, M.A., Chacón, B., 2003. Mid-depth calcareous contourites in the latest Cretaceous of Caravaca (Subbetic Zone, SE Spain). Sedimentary Geology 163, 131-146.

Martínez del Olmo, W., Leret, G., Megías, A.G., 1982. El límite de la plataforna carbonatada del Cretácico Superior en la zona prebética. Cuademos de Geología Ibérica 8, 597-614.

Molina, E., Canudo, J.I., Martínez-Ruiz, F., Ortiz, N., 1994. Integrated stratigraphy across the Paleocene/Eocene boundary at Caravaca, Southem Spain. Eclogae Geologicae Helveticae 87, 47-61.

Molina, E., Arenillas, I., Arz, J.A., 1996. The Cretaceous/Tertiary boundary mass extinction in planktic foraminifera at Agost (Spain). Revue de Micropaleontology 39, 225-243.

Molina, E., Arenillas, I., Arz, J.A., 1998. Mass extinction in planktic foraminifera at the Cretaceous/Tertiary boundary in subtropical and temperate latitudes. Bulletin de la Société Géologique de France 169 (3), 351-363.

Molina, E., Alegret, L., Arenillas, I., Arz, J.A., 2005. The Cretaceous/ Paleogene boundary at the Agost section revisited: paleoenvironmental reconsuction and mass extinction pattem. Joumal of Iberian Geology 31 (1), 135-150

Muñoz, J.A., 2002. Alpine tectonics I: the Alpine system north of the Betic Cordillera. In: Gibbons, W., Moreno, T. (Eds.), Geology of Spain. Geological Society of London, London, pp. 37-385.
Olivet, J.L., 1996. La cinématique de la plaque ibérique. Bulletin des Cen de Recherches Exploration-Production Elf-Aquitaine 20, 131-195.

Orue-Etxebarria, X., Pujalte, V., Bernaola, G., Apellaniz, E., Baceta, J.I., Payros, A., Nuñez-Betelu, K., Serra-Kiel, J., Tosquella, J., 2001. Did the Late Paleocene thernal maximum affect the evolution of larger foraminifers? Evidence from calcareous plankton of the Campo section (Yrenees, Spain). Marine Micropaleontology 41, 45-71.

Pardo, A., Ortiz, N., Keller, G., 1996. Latest Maastrichtian and Cretaceous-Tertiary boundary foraminiferal tumover and environmental changes at Agost, Spain. In: MacLeod, N., Keller, G. (Eds.), The Cretaceous-Tertiary Mass Extinction: Biotic and Environmental Events. W.W. Norton \& Co, New York, pp. 139-171.

Philip, J., Floquet, M., 2000. Late Maastrichtian (69.5-65 Ma). In: Crasquin, S. (Ed.), Atlas Peri-Tethys, Palaeogeographic Maps, Explanatory Notes. CCGM/CGMW, Paris, pp. 145-152.

Puga, E., Díaz le Federico, A., Nieto, J.M., 2002. Tectonos ratigraphic subdivision and perological characterisation of the deepest complexes of the Betic zone: a review. Geodinamica Acta 15, 23-43.

Puigdefábregas, C., Souquet, J.A., 1986. Tecto-sedimentary cycles and depositional sequences of the Mesozoic and Tertiary from the Pyrenees. In: Banda, E., Wickham, S.M. (Eds.), The Geological Evolution of the Pyrenees. Tectonophysics, vol. 129, pp. 173-203.

Pujalte, V., Orue-Etxebarría, X., Baceta, J.I., Payros, A., 1994. Late Cretaceous-Middle Eocene. Sequence stratigraphy and biostratigraphy of the SW and W Pyrenees (Pamplona and Basque Basins, Spain). Libre des Excursions du Premier Congrès Français de Stratigraphie. Excursion Géologique. G.E.P., pp. 1-118.

Pujalte, V., Robles, S., Orue-Etxebarria, X., Baceta, J.I., Payros, A., Larruzea, I.F., 2000. Uppennost Cretaceous-Middle Eocene strata of the Basque-Cantabrian region and Western Pyrenees: a sequence stratigraphic perspective. Revista Sociedad Geológica España 13, 191-211.

Reicherter, K.R., Pletsch, T.K., 2000. Evidence for a synchronous circum-Iberian subsidence event and its relation to the AfricanIberian plate convergence in the Late Creceous. Terra Nova 12, 141-147.

Salas, R., Guimerá, J., Mas, R., Martín-Closas, C., Meléndez, A., Alonso, A., 2001. Evolution of the Mesozoic central Iberian Rift System and its Cainozoic inversion (Iberian Chain). In: Ziegler, P.A., Cavazza, W., Rotertson, A.H.F., Crasquin-Soleau, S. (Eds.), Peri-Tethys Memoir 6: Peri-Tethyan Rift Wrench Basins and Passive Margins. Mémoires du Muséum National d'Historie Naturelle, vol. 186. Muséum National d'Historie Naturelle, Paris, pp. 145-185.

Savostin, L.A., Sibuet, J.-C., Zonenshain, L.P., Le Pichon, X., Roulet, M.-J., 1986. Kinematic evolution of the Tethys belt from the Atlantic Ocean to the Pamirs since the Triassic. Tectonophysics $123,1-35$.

Serra-Kiel, J., Hottinger, L., Caus, E., Drobne, K., Ferràndez, C., Jauhri, A.K., Less, G., Pavlovec, R., Pignatti, J., Samsó, J.M., Schaub, H., Sirel, E., Strougo, A., Tambareau, Y., Tosquella, J., Zalrevs-kaya, E., 1998. Larger foraminiferal bios ratigraphy of the Tethyan Paleocene and Eocene. Bulletin de la Société Géologique de France 169 (2), 281-299.

Srivastava, S.P., Roest, W.R., Kovacs, L.C., Oakley, G., Levesque, S., Verhoef, J., Macnab, R., 1990. Motion of Iberia since the Late Jurassic: results from detailed aeromagnetic measurements in the Newfoundland Basin. Tectonophysics 184, 229-260.

Van Morkhoven, F.P.C.M., Berggren, W.A., Edwards, A.S., 1986. Cenozoic cosmopolitan deep-water benthic foraminifera. In Oertli, H.J. (Ed.), Elf Aquitaine. Memoir, vol. 11 
Vera, J.A., 1986. Las zonas extemas de las Cordilleras Béticas. In: Libro Jubilar J.M. Ríos. I.G.M.E. Tomo II, 218-237.

Vera, J.A., 1988. Evolución de los sistemas de depósito en el margen Ibérico de la Cordillera Bética. Revista de la Sociedad Geológica de España 1 (3-4), 373-391.

Vera, J.A., 2001. Evolution of the South Iberian Continental Margin. In: Ziegler, P.A., Cavaza, W., Robertson, A.H.F., Crasquin-Soleau, S. (Eds.), Peri-Tethys Memoir 6: Peri-Tethyan Rift Wrench Basins and Passive Margins. Mémoires du Muséum National d'Historie Naturelle, vol. 186, pp. 109-143. Paris.

Vera, J.A., (Coord.), 2004. Cordillera Bética y Baleares. In: Vera, J.A. (Ed.), Geología de España. SGE-IGME, Madrid, 347-464.

Vera, J.A., García Hemández, M., López Garrido, A.C., Comas, M.J., Ruiz Ortiz, P.A., Martín-Algarra, A., 1982. La Cordillera Bética. El Cretácico de España. Univ. Complutense, Madrid, pp. 515-631.

Vera, J.A., Molina, J.M., Aguado, R., 2003. La Fonnación Ma jalcorón (Calcarenitas con Microcodium, Paleoceno, Subbetico): Situación e interpretación en el Terciario de la Cordillera Ibérica. Geo-Temas 5, 243-246.

Vergès, J., García-Senz, J., 2001. Mesozoic evolution and Cainozoic inversion of the Pyrenean Rift. In: Ziegler, P.A., Cavazza, W., Robertson, A.H.F., Crasquin-Soleau, J. (Eds.), Peri-Tethys Memoir 6: Peri-Tethyan Rift Wrench Basins and Passive Margins. Mémoires du Muséum National d'Historie Naturelle, 186, pp. 187-212. Paris.
Vilas, L., Dabrio, C., Peláez, J.R., García Hemández, M., 2001. Dominios sedimentarios generados durante el período extensional Cretácico inferior entre Cazorla y Hellín (Béticas extemas). Su implicación en la estructura actual. Revista de la Sociedad Geológica de España 14, 113-122.

Vilas, L., Martín-Chivelet, J., Arias, C., 2003. Integration of subsidence and sequence stratigraphic analyses in the Cretaceous carbonate platforms of the Prebetic (Jumilla-Yecla Region), Spain. Palaeogeography, Palaeoclimatology, Palaeoecology 200, 107-129.

Walliser, O.H. (Ed.), 1996. Global Events and Event Stratigraphy in the Phanerozoic. Springer-Verlay, New York. 333 pp.

Wallrabe-Adams, H.J., Altenbach, A.V., Kempe, A., Kulnt, W., Schaefer, P., 2005. Facies development of ODP Leg 173 sediments and comparison with tectono-sedimentary sequences of compressional Iberian plate margins - a general overview. Joumal of Iberian Geology 31 (2), 235-351.

Wildi, W., 1983. La Chaine Tello-rifaine (Algérie, Maroc, Tunisie): stucture stratigraphie et évolution du Trias au Miocène. Revue de Géologie Dynamique et de Géographie Physique 24 (3), 21-297.

Ziegler, P.A., 1988. Evolution of the Arctic-North Atlantic and the Western Tethys. American Association of Petroleum Geologists, Memoir $43198 \mathrm{pp}$. 